\author{
UNIVERSIDADE DE BRASÍLIA \\ FACULDADE DE CIÊNCIAS DA SAÚDE \\ PROGRAMA DE PÓS-GRADUAÇÃO EM BIOÉTICA
}

RAYLLA ALBUQUERQUE SILVA

VIOLÊNCIA OBSTÉTRICA À LUZ DA DECLARAÇÃO UNIVERSAL SOBRE BIOÉTICA E DIREITOS HUMANOS: PERCEPÇÃO DOS ESTUDANTES DA ÁREA DA SAÚDE

Dissertação apresentada como requisito parcial para obtenção do grau de Mestre em Bioética pelo Programa de Pós-graduação em Bioética da Universidade de Brasília.

Orientador: Prof. Dr. Natan Monsores de Sá

BRASÍLIA 
RAYLLA ALBUQUERQUE SILVA

\title{
VIOLÊNCIA OBSTÉTRICA À LUZ DA DECLARAÇÃO UNIVERSAL SOBRE BIOÉTICA E DIREITOS HUMANOS: PERCEPÇÃO DOS ESTUDANTES DA ÁREA DA SAÚDE
}

\begin{abstract}
Dissertação apresentada como requisito parcial para obtenção do grau de Mestre em Bioética pelo Programa de Pós-graduação em Bioética da Universidade de Brasília.
\end{abstract}

Orientador: Prof. Dr. Natan Monsores de Sá

Aprovada em 13 de fevereiro de 2017.

BANCA EXAMINADORA

Dr. Natan Monsores de Sá (Presidente)

Universidade de Brasília

Dra. Aline Albuquerque

Advocacia Geral da União

Dra. Alessandra Arrais

FEPECS

Dra. Glória Maria

Universidade de Brasília (Suplente) 
À vó Maria, que completa quatro anos de saudade. 


\section{AGRADECIMENTOS}

Ao meu orientador, Natan Monsores, por todo o apoio e paciência a mim dedicados, antes mesmo de assumir esse papel.

Às integrantes da banca, as professoras Aline Albuquerque, Alessandra Arrais e Glória Maria, por terem aceitado, prontamente, o convite para integrá-la.

Ao coordenador da Cátedra de Bioética da UnB, Volnei Garrafa, por todo o incentivo e apoio oferecidos desde que cheguei ao programa. 


\section{RESUMO}

Pesquisas em todo o mundo demonstram que mulheres têm sido vítimas de negligência, violência física, violência verbal e violência sexual dentro das instituições de saúde - em especial ao dar à luz. Considerando o papel dos profissionais no que se refere a esse cenário, o presente estudo teve como objetivo conhecer a percepção dos estudantes da área da saúde sobre a violência obstétrica e sua relação com a Bioética, conforme princípios previstos na Declaração Universal sobre Bioética e Direitos Humanos. Realizou-se pesquisa exploratória de abordagem mista, com 102 estudantes em todos os níveis de formação. O instrumento utilizado foi o questionário estruturado, disponibilizado por meio eletrônico, composto por questões abertas e fechadas. A análise de dados incluiu técnicas de estatística descritiva para os dados quantitativos e análise de conteúdo para os qualitativos, à luz da Declaração Universal sobre Bioética e Direitos Humanos. A violação aos princípios do "Respeito à Vulnerabilidade Humana e pela Integridade Individual" e "Dignidade Humana e Direitos Humanos" foram indicados por aproximadamente 80\% dos participantes como relacionados com a ocorrência de Violência Obstétrica. A vulnerabilidade da mulher no processo de parto está relacionada, principalmente, ao desconhecimento sobre seus direitos, seu corpo e sobre os tipos de assistência. A adoção de condutas desnecessárias e sem respaldo científico configuram violações à integridade corporal da mulher, à sua dignidade e aos direitos humanos. Embora a ocorrência de violência obstétrica seja multifatorial, as principais práticas caracterizadas pelos participantes como violência referem-se a condutas não éticas. Os achados da pesquisa evidenciaram a importância da utilização de referenciais bioéticos para o enfrentamento da violência obstétrica.

Palavras-chave: Bioética; Violência; Direitos Humanos; Humanização; Parto. 


\begin{abstract}
The researches around the world show that women have been victims of negligence, physical violence, verbal violence and sexual violence in health institutions especially when giving birth. Whereas the role of professionals in this scenario, this present study aims to know the students' perception in the field of health on the obstetric violence and its relation with bioethics, accordingly with principles referred to in the Universal Declaration on Bioethics and Human Rights. An exploratory research of mixed approach was conducted with 102 students at all levels of training. The instrument used was a structured questionnaire made available by electronic means and it was composed by open and closed questions. The data analysis included descriptive statistics techniques for quantitative data and content analysis for qualitative data in the light of the Universal Declaration on Bioethics and Human Rights. The infringements of the principles of "respect for human vulnerability and individual integrity" and "human dignity and human rights" were indicated by about $80 \%$ of the participants as related to an occurrence of obstetric violence. The woman vulnerability when giving a birth is mainly related to the lack of knowledge about her rights, her body and types of assistance. The adoption of unnecessary conducts and without scientific support constitutes violations of women's bodily integrity, dignity and human rights. Although the occurrence of obstetric violence is multifactorial, the most practices described by the participants as violence refer to unethical behavior. The research findings highlight the relevance of the use of bioethical references to combat obstetric violence.
\end{abstract}

Keywords: Bioethics; Violence; Human Rights; Humanization; Childbirth. 


\section{LISTA DE TABELAS}

Tabela 1 - Características sociodemográficas da amostra......................................39

Tabela 2 - Credo confessional representado na amostra......................................41

Tabela 3 - Características acadêmicas da amostra...............................................42

Tabela 4 - Conhecimento auto referido em bioética pelos participantes....................50 


\section{LISTA DE QUADROS}

Quadro 1 - Caracterização da violência obstétrica, pelos estudantes. . .44

Quadro 2 - Fatores que contribuem para a ocorrência de violência obstétrica, na visão dos estudantes. .45

Quadro 3 - Princípios Bioéticos e Violações Obstétricas. 52 


\section{LISTA DE ABREVIATURAS E SIGLAS}

DUBDH - Declaração Universal sobre Bioética e Direitos Humanos

DUDH - Declaração Universal dos Direitos Humanos

FIOCRUZ - Fundação Oswaldo Cruz

HRSAM - Hospital Regional de Samambaia

IBC - International Bioethics Committee of UNESCO

INEP - Instituto Nacional de Estudos e Pesquisas

MPF - Ministério Público Federal

OMS - Organização Mundial da Saúde

PNH - Política Nacional de Humanização

REHUNA - Rede pela Humanização do Parto e Nascimento

SUS - Sistema Único de Saúde

UNB - Universidade de Brasília

UNESCO - Organização das Nações Unidas para a Educação, a Ciência e a Cultura 


\section{SUMÁRIO}

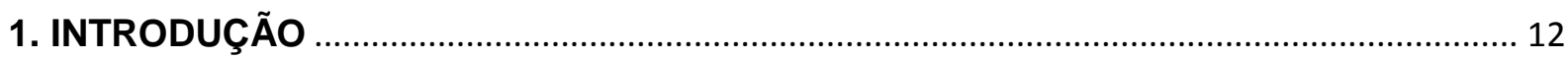

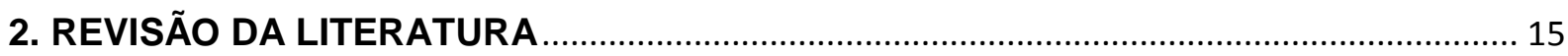

2.1 PANORAMA DA VIOLÊNCIA OBSTÉTRICA.............................................................. 15

2.1.1 Tipificação da Violência Obstétrica............................................................................ 17

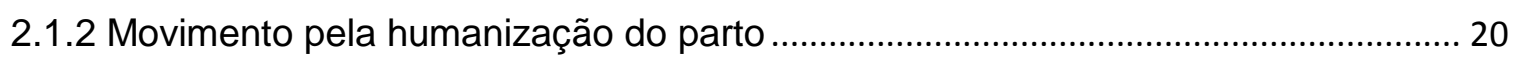

2.1.3 Referenciais a serem utilizados na assistência ao parto ........................................... 22

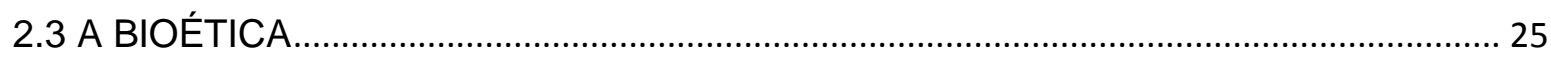

2.3.1 Dignidade Humana e Direitos Humanos...………………………………………. 26

2.3.2 Benefício e Dano ................................................................................................ 27

2.3.3 Autonomia e Responsabilidade Individual........................................................... 28

2.3.4 Consentimento e indivíduos sem a capacidade para consentir................................ 29

2.3.5 Respeito pela Vulnerabilidade Humana e pela Integridade Individual ..................... 30

2.3.6 Privacidade e Confidencialidade .............................................................................. 31

2.3.7 Igualdade, Justiça e Equidade ………………………………………………...... 32

2.3.8 Não discriminação e não estigmatização …………………………………………..... 33

2.3.9 Respeito pela Diversidade Cultural e pelo Pluralismo ............................................... 34

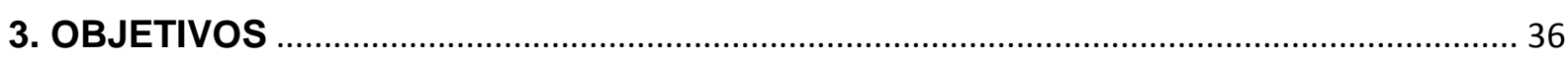

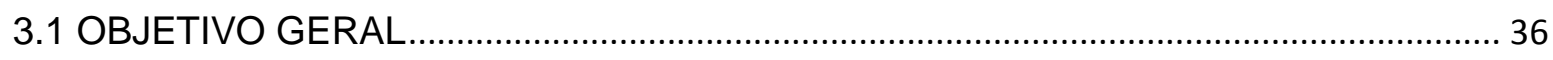

3.2 OBJETIVOS ESPECÍFICOS ......................................................................................... 36

4. MÉTODO

4.1 PARTICIPANTES/SUJEITOS …………………………………………………… 37

4.2 INSTRUMENTO DE PESQUISA ............................................................................. 37

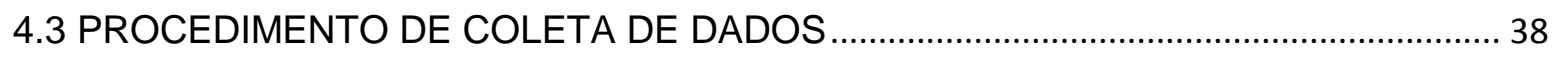

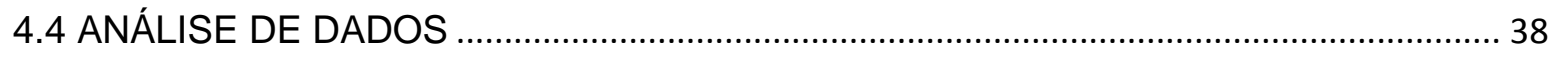

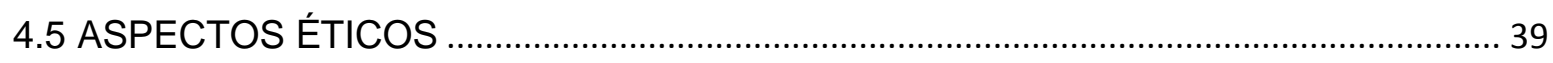

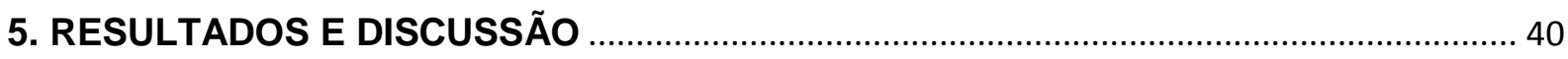

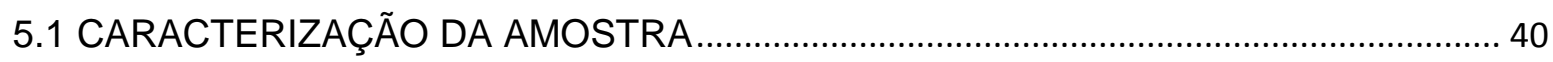

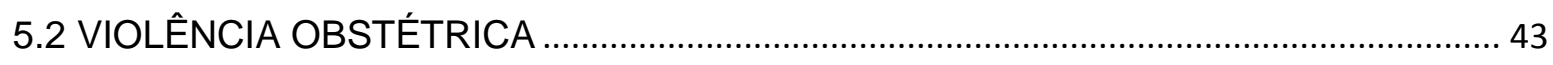

5.2.1 Percepção e conhecimento dos estudantes sobre a violência obstétrica ................ 43

5.2.2 A violência obstétrica dentro instituição de ensino ....................................................... 47 
5.3 BIOÉTICA E A VIOLÊNCIA OBSTÉTRICA, UMA APROXIMAÇÃO ................................ 50

5.3.1 Dignidade Humana e Direitos Humanos........................................................................ 53

5.3.2 Respeito pela Vulnerabilidade Humana e pela Integridade Individual...................... 54

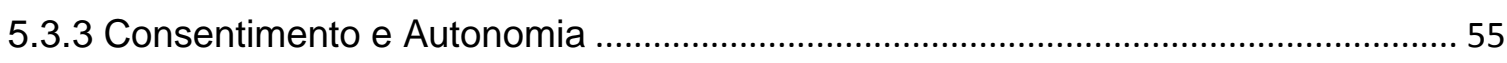

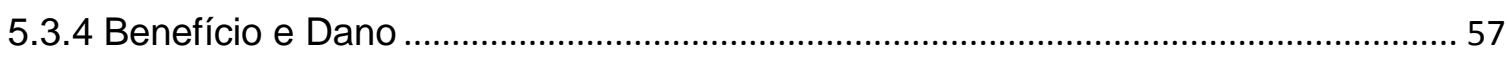

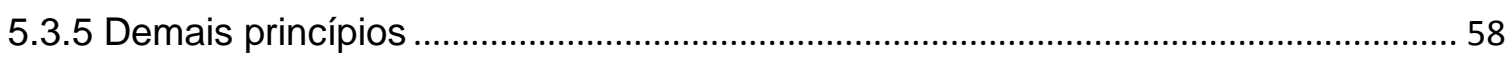

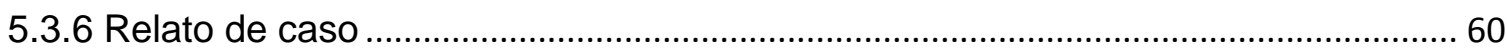

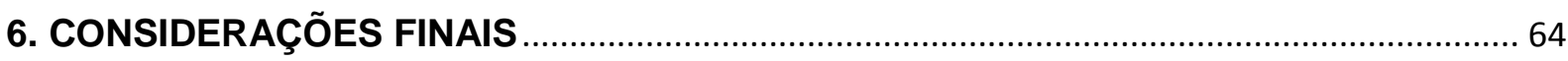

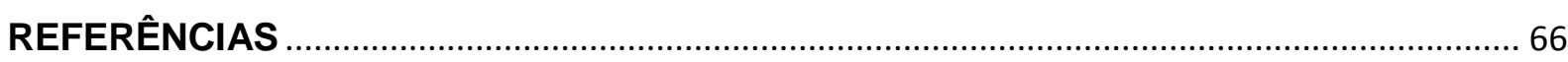

APÊNDICE A - QUESTIONÁRIO ELETRÔNICO APLICADO .................................................... 75

ANEXO A - PARECER DE APROVAÇÃO PELO COMITÊ DE ÉTICA .................................... 81

ANEXO B - DECLARAÇÃO UNIVERSAL SOBRE BIOÉTICA E DIREITOS HUMANOS ..... 88 


\section{INTRODUÇÃO}

Pesquisas em todo o mundo demonstram que mulheres têm sido vítimas de negligência, violência física, violência verbal e violência sexual dentro das instituições de saúde - em especial ao dar à luz. Uma em cada quatro mulheres refere ter sido vítima de algum tipo de violência durante o atendimento ao parto, no Brasil (1).

Embora haja avanços na garantia e proteção de direitos das mulheres durante a gravidez, inúmeros abusos ainda ocorrem: relativização da autonomia, agressões verbais e físicas, coação, lesões corporais, privação de acompanhante, negligência profissional e má-fé, entre outras formas de violência. Um documento elaborado pela Organização Mundial de Saúde (OMS) descreve que, apesar do direito à saúde sexual e reprodutiva ter garantido mais acesso à assistência institucional para o parto, a qualidade desses serviços ainda deixa muito a desejar. O material relata que muitas mulheres sofrem "abusos, desrespeitos e maus-tratos durante o parto nas instituições de saúde" no mundo inteiro (2).

O acesso a essa assistência institucional ao parto acompanhou uma efetiva melhoria nos indicadores de mortalidade materna e neonatal - que estão associados aos avanços no uso de técnicas de assepsia e de antibióticos, à disponibilidade de tecnologias para diagnóstico e terapia e às melhorias nas condições de vida da população, segundo Rattner (3). Porém, apesar dos avanços, as metas do milênio relativas à redução da mortalidade, materna e neonatal, não foram atingidas. Conforme a autora, a estabilização desses indicadores, no Brasil, nos últimos anos está associada a uma inadequação na qualidade da assistência - pautada na deficiência das relações interpessoais, que se tornaram desumanizadas e mecanizadas.

Davis-Floyd (4) explica que os sistemas de saúde são fundamentados em seu contexto cultural e incorporam os valores, crenças e preconceitos da sociedade à qual pertencem. Para a antropóloga, o sistema ocidental é fortemente orientado pela 
tecnologia e executado por meio de grandes instituições geridas por ideologias patriarcais, dentro de um contexto econômico.

Portanto, as "relações de poder assimétricas e geradoras de desigualdades, presentes na sociedade contemporânea, e incorporadas à cultura das relações sociais estabelecida em algumas instituições" (5) constituem a violência institucional. As violências praticadas pelos prestadores do serviço de saúde estão pautadas em um sistema altamente hierarquizado e que se apropria das decisões vitais sobre o corpo do paciente.

Nesse sentido, a assistência ao parto tem se caracterizado pela prevalência do poder do profissional de saúde sobre a parturiente e por um processo de dominação simbólica que pode recair na desumanização e constituir-se em atos de violência (6).

A violência obstétrica se refere a toda violência praticada no contexto da assistência à gestação, parto, pós-parto e abortamento e é caracterizada, como já afirmado, por agressão física, psicológica, verbal, simbólica e sexual, assim como pela negligência na assistência e pela discriminação. Segundo a OMS, esse tratamento "não apenas viola os direitos das mulheres ao cuidado respeitoso, mas também ameaça o direito à vida, à saúde, à integridade física e à não discriminação"(2).

Considerando que "a discussão bioética surge (...) para contribuir na procura de respostas equilibradas ante os conflitos atuais" (7), o debate em seu âmbito acerca da violência obstétrica, enquanto conduta profissional e institucional, se justifica em função do papel político e social das reflexões bioéticas.

Diante desta possível aproximação, buscou-se conhecer a compreensão de estudantes da área da saúde sobre a violência obstétrica e a bioética. Por se tratar de um estudo exploratório, não há pretensão de esgotar o tema e tampouco de propor soluções ao problema - uma vez que ele tem origem multifatorial -, mas sim, fornecer elementos para a discussão, sob uma perspectiva diferente.

Considerando que a violência obstétrica configura violação aos direitos humanos, à dignidade humana, dentre outros princípios presentes na Declaração 
Universal sobre Bioética e Direitos Humanos (8), por meio das respostas dadas pelos estudantes que responderam ao instrumento de pesquisa, foi possível estabelecer uma relação, ainda que sem pretensões quantitativas, entre a ocorrência de violência obstétrica e o desrespeito aos princípios bioéticos, que serão detalhados no decorrer deste material.

Os achados desta pesquisa serão utilizados como base para o estudo a ser realizado em futura pesquisa de doutorado. Desta forma, esta pesquisa estabelece um quadro inicial de referência para se compreender a influência do ensino da ética e de temas relacionados ao cuidar humanizado do parto, em profissões de saúde, na existência ou redução de práticas violentas contra a mulher em ambiente hospitalar. 


\section{REVISÃO DA LITERATURA}

\subsection{PANORAMA DA VIOLÊNCIA OBSTÉTRICA}

Durante séculos, o cuidado e a assistência ao parto eram realizados dentro dos domicílios, por familiares e por parteiras, configurando uma prática predominantemente feminina. Segundo Rezende (9), os primeiros textos com referência à assistência prestada às gestantes por outras mulheres datam de 2500 a.C.. Os registros mostram que "desde cedo as parteiras se arrogaram o direito privativo de socorrer as parturientes, pedindo auxílio aos médico-sacerdotes, seus parceiros na ignorância presumida, apenas quando malogrados os procedimentos primitivos e exorcismos empregados para conjurar as distocias"(9). Cabe salientar que o fragmento de texto aqui citado, escrito por um médico, já aponta certa recusa por parte do autor em reconhecer o importante papel das parteiras no acompanhamento de partos. Como contraponto a esta postura, pode-se citar o clássico exemplo de como o saber empírico das parteiras contribuiu para redução de mortalidade por infecções puerperais, pelo ato da lavagem de mãos, que não era praticado entre médicos do Século XIX (10). Nesta mesma obra, o autor recomenda uma série de práticas sem evidências científicas ou com prejuízos já constatados por revisões sistemáticas, como é o caso da episiotomia e a manobra de Kristeller.

O surgimento da obstetrícia como disciplina científica, nos séculos XVII e XVIII, tornou a assistência ao parto gradativamente uma especialidade médica. Essa apropriação destituiu as parteiras do direito de exercerem seu ofício, desqualificando seu saber, e instituiu o parto horizontal, que subtraiu o protagonismo da mulher no processo de parturição. $O$ advento do fórceps obstétrico também trouxe mudanças na assistência ao parto, e se consolidou a ideia de que este seria um evento perigoso (11) e que necessita de assistência especializada.

No Brasil, a história da parturição começa a ser registrada apenas com a chegada dos colonizadores europeus. Enquanto as portuguesas contavam com assistência das parteiras, trazidas na expedição, que agiam conforme os 
procedimentos europeus da época: partos realizados em domicílio com a necessidade de resguardo; mulheres indígenas davam à luz em suas ocas ou mesmo na floresta, em posição vertical e, muitas vezes, sozinhas - sendo acompanhadas de uma mulher indígena mais experiente, em caso de primeira gestação $(12,13)$.

A primeira escola de medicina brasileira foi fundada em 1808, na Bahia, seguida pela inauguração de outra no Rio de Janeiro no mesmo ano. Ambas contam com o ensino de cirurgia, anatomia e obstetrícia - embora a última especialidade tenha incluída apenas por volta de 1818 na escola da Bahia (14).

Apenas em 1930 a literatura médica recomenda com maior ênfase o hospital como local ideal e mais seguro para que as mulheres possam dar à luz. A transição do ambiente domiciliar para o hospitalar, um dos aspectos iniciais da medicalização do parto, teve início no meio urbano e foi progredindo para o rural (15). Em relação a essa transição, Mamede e colaboradores (16), relatam que

\begin{abstract}
A transferência do parto do ambiente doméstico para o contexto hospitalar foi acompanhada por uma série de transformações no processo de parturição. A parturiente e 0 feto perdem o papel de protagonistas nesse processo, assumindo uma posição passiva, enquanto os profissionais passam a tomar o controle sobre o nascimento, realizando uma série de intervenções e modificando as práticas obstétricas. (16)
\end{abstract}

Com a efetivação da assistência obstétrica pautada na figura do médico, a gravidez passou a não mais ser conduzida como um processo fisiológico. O parto tornou-se um evento cirúrgico, marcado pela utilização de fórceps, pela indução medicamentosa e por episiotomias desnecessárias, onde a mulher deveria estar imobilizada, com as pernas abertas e levantadas para facilitar intervenções realizadas por pessoas desconhecidas. Assim, os profissionais da saúde, que deveriam ser coadjuvantes, colocaram-se como protagonistas da experiência do parto $(11,17)$.

Conforme descrito por Davis-Floyd (4), a sociedade ocidental está, de maneira geral, inserida dentro do modelo tecnocrático da medicina. Nesse modelo, o corpo feminino é visto como uma máquina defeituosa, que precisa de reparos. Conforme detalhado pela autora, 
como a produção fabril de bens se tornou uma metáfora organizadora central para a vida social, tornou-se também a metáfora dominante para o nascimento: o hospital tornou-se a fábrica, o corpo da mãe tornou-se a máquina e o bebê tornou-se 0 produto de um industrial processo de manufatura. Assim, a obstetrícia foi encarregada de desenvolver ferramentas e tecnologias para a manipulação e aperfeiçoamento do processo inerentemente defeituoso de nascimento e para fazer 0 nascimento estar em conformidade com o modelo de linha de montagem da produção da fábrica. (4)

O modelo tecnocrático, apresentado pela autora (4), está pautado em um sistema de valores fundamentais como a ciência, tecnologia, o lucro econômico e a regência institucional patriarcal. Dentro desses valores centrais - tanto na medicina quanto na sociedade em geral - a tecnologia está em destaque. Isso se reflete, para a autora, no fato de que a maioria dos procedimentos rotineiramente utilizados na prática obstétrica "têm pouca ou nenhuma evidência científica para justificá-los. Eles são rotineiramente realizados não porque eles fazem sentido científico, mas porque eles fazem sentido cultural“(4).

Adotadas sem comprovação científica, as instituições e profissionais de saúde submetem as mulheres a normas rígidas e muitas vezes desnecessárias, que não respeitam seus corpos e os seus ritmos naturais. Impedidas de exercer seu protagonismo, são tornadas submissas a situações que por vezes as infantiliza, fragiliza, descaracteriza e violenta.

As práticas impostas às mulheres, que violam sua intimidade ou pudor, e incidem sobre sua integridade sexual e reprodutiva, como assédio, exames de toque desnecessários, invasivos, agressivos e constantes, episiotomia, lavagem intestinal, cesariana e ruptura de membranas sem consentimento informado, além de exames repetitivos de mamas e mamilos sem necessidade, esclarecimento e sentimento, configuram-se como violência obstétrica (18).

\subsubsection{Tipificação da Violência Obstétrica}

A expressão "violência obstétrica" é usada para descrever diversas formas de violências ocorridas durante o cuidado obstétrico. Conforme tipificada em legislação aprovada na Venezuela, ela se refere a: 
Qualquer conduta, ato ou omissão por profissional de saúde, tanto em público como privado, que direta ou indiretamente leva à apropriação indevida dos processos corporais e reprodutivos das mulheres, e se expressa em tratamento desumano, no abuso da medicalização e na patologização dos processos naturais, levando à perda da autonomia e da capacidade de decidir livremente sobre seu corpo e sexualidade, impactando negativamente a qualidade de vida de mulheres. (19)

A violência obstétrica se refere a toda violência praticada no contexto da assistência à gestação, parto, pós-parto e abortamento e é caracterizada, como já explicitado, por agressão física, psicológica, verbal, simbólica e sexual, assim como pela negligência na assistência e pela discriminação. (1)

De acordo com o Dossiê "Parirás com dor" (18), os atos considerados como violência obstétrica podem ser classificados de acordo com o seu o seu caráter, podendo ser físico, que consiste em ações que interferiam, causem dor ou dano físico sem recomendação baseada em evidência científica, como privação de alimentos, tricotomia (procedimento de raspagem de pelos), manobra de Kristeller, uso rotineiro de ocitocina, entre outros. O caráter psicológico é aquele em que ações verbais ou comportamentais causem na mulher sentimentos de abandono, inferioridade, vulnerabilidade e medo - tais como ameaças, mentiras, grosserias, piadas e humilhações.

Dentre as diversas conceituações possíveis para a violência obstétrica, Bowser e Hill (20) elencam algumas categorias de desrespeito e abuso nas instituições de saúde, associando-as aos direitos correspondentes. As categorias propostas são: abuso físico, cuidado não consentido, cuidado não confidencial, cuidado não digno, discriminação baseada em certos atributos, abandono do cuidado e detenção nos serviços. As autoras destacam ainda a importância do reconhecimento e defesa dos direitos humanos enquanto estratégia para diminuição dos abusos no atendimento ao parto e nascimento.

Nas categorias de direitos correspondentes propostos pelas autoras (20) há referência a princípios bioéticos. No documento, elas citam o respeito aos direitos humanos, consentimento informado e à confidencialidade e privacidade como sendo altamente relevantes para um cuidado respeitoso ao parto e nascimento.

Em conformidade com essa categorização é possível identificar, em estudo realizado com população feminina encarcerada no Brasil, a presença de todas as 
categorias de violência propostas acima pelas autoras, com destaque para a "discriminação baseada em certos atributos". O percentual de mulheres que tiveram acompanhamento pré-natal adequado foi duas vezes menor do que o encontrado dentre as mulheres sem restrição de liberdade - mesmo quando comparados às usuárias do SUS, que possuem condições sociais semelhantes. E um terço das mulheres referiu o uso de algemas na internação (21). Deste estudo, pode-se inferir um desrespeito ao princípio bioético da não-discriminação e não-estigmatização.

A ocorrência de violações aos princípios do respeito à autonomia, consentimento informado e vulnerabilidade pode ser percebida conforme estudo conduzido em uma maternidade pública, no Recife. A baixa escolaridade das gestantes e a assistência prestada por profissional médico foram identificadas como fatores de suscetibilidade à ocorrência de violência obstétrica. Os autores (22) atribuem os achados ao fato de que uma maior escolaridade representaria mais acesso à informação sobre os cuidados, permitindo questionar as condutas o que desencorajaria os profissionais. Em contrapartida, a assistência pelo profissional médico estaria mais pautada em abordagens intervencionistas, o que atribuem à formação recebida por esses profissionais.

A negligência foi apontada como sendo o tipo de violência mais frequente, conforme revisão sistemática sobre a violência obstétrica no Brasil, conduzida por Santos e Souza (23). Para os autores, ela pode ser caracterizada por peregrinação nas unidades de saúde, abandono nos leitos, falta de manejo da dor, dentre outros. Em seguida, apareceram a violência verbal e violência física, respectivamente, que seriam executadas, principalmente, pelos médicos e profissionais de enfermagem.

De acordo com Rodrigues et al (24), a peregrinação no período reprodutivo constituiria uma forma de violência obstétrica. Para os autores, a peregrinação constitui grande fator de estresse e vulnerabilidade às gestantes, podendo ser caracterizada como violência de caráter psicológico, por se tratar de "conduta institucional que causou sentimentos de abandono, insegurança e instabilidade emocional, fatores altamente prejudiciais a um parto seguro" (24).

Conforme avaliação das puérperas atendidas em determinada maternidade sobre o que caracterizaria o mau atendimento recebido, houve referências à 
ausência de manejo da dor, realização de procedimentos sem consentimento, tratamento grosseiro, exposição desnecessária da intimidade, dentre outros. Segundo Aguiar e d'Oliveira (25), esses relatos indicam a banalização do sofrimento das parturientes por parte dos profissionais de saúde.

Algumas implicações da violência obstétrica sobre a morbidade e mortalidade maternas são descritas por Diniz et al (26), tais como o manejo agressivo do parto vaginal e seus riscos associados, a coerção à realização de cesáreas, a negligência e demora no atendimento às mulheres (durante o parto e abortamento). Para os autores, a formação dos profissionais de saúde e a forma de organização dos serviços configuram causas dessa violência praticada.

Diante desses fatores, os autores (26) sugerem formas de identificar, prevenir e mitigar a ocorrência de violência obstétrica. Dentre as propostas, cabe destaque à de promover "intervenções na formação dos recursos humanos durante a graduação e a especialização e na formação continuada", através da inclusão do estudo dos direitos (das mulheres, sexuais e reprodutivos), do investimento na formação de obstetrizes e enfermeiras obstetras e modificação das rotinas e ambiências de ensino. As demais propostas se referem à informação e o fortalecimento da autonomia de usuárias e famílias, bem como a visibilização do problema e responsabilização dos atores.

\subsubsection{Movimento pela humanização do parto}

Dentro do modelo humanístico de atenção à saúde, descrito por Davis-Floyd (4), há o reconhecimento da influência das emoções sobre o corpo. Essa nova perspectiva surgiu como reação ao modelo tecnocrático em saúde, que promovia uma separação entre mente e corpo, e leva em conta os aspectos biológicos, psicológicos e ambientais relacionados ao cuidado em saúde. Para a autora, as implicações da noção de que a mente afeta o que acontece no corpo, no que se refere ao parto, são óbvias e profundas. Segunda ela, 
O humanismo no parto permite a possibilidade de que as emoções da mulher trabalhadora possam afetar o progresso de seu trabalho e que os problemas no trabalho possam ser tratados mais eficazmente através do apoio emocional do que através da intervenção tecnológica. (4)

Configurando uma das possibilidades de enfrentamento da violência obstétrica, surge o movimento pela humanização do parto. Embora o termo humanização não possua consenso em sua definição, refere-se a mudanças no modelo de atenção pautada em boas práticas no cuidado em saúde.

Essa proposta busca devolver à mulher o papel de protagonista neste evento, por entendê-lo como um processo fisiológico natural e feminino, garantindo-lhe o "direito a escolha, valorizando a participação da família e procurando incentivar ao máximo a participação ativa do acompanhante na hora do parto". (27)

Rattner (3) relata a existência de um forte movimento internacional, em defesa da humanização do parto e nascimento, surgido em resposta à violência institucional. Para a autora, o termo humanização é polissêmico, mas sua caracterização, por meio da Política Nacional de Humanização (PNH), adotada no Brasil, é transversal a vários sentidos,

\footnotetext{
incorporando questões referentes a: ambiência, universalidade, processo de trabalho, gestão do sistema, controle social, subjetividades de cuidadores e receptores do cuidado, e outros aspectos relevantes. A proposta / aposta ética-estética-política é um projeto de sociedade baseada na equidade, em que o acesso a serviços de saúde com humanização e qualidade reflete a garantia da cidadania numa sociedade democrática. (3)
}

A Política Nacional de Humanização, implantada no país em 2003, propõe uma mudança nos modelos de atenção e gestão da saúde. Dentre seus princípios, a transversalidade prevê a presença da proposta em todas as políticas e programas dentro do Sistema Único de Saúde (SUS) bem como o reconhecimento do papel de usuários e trabalhadores para a efetivação desta mudança.

Dentro do cenário de atuação em defesa da humanização do parto e nascimento, há que se destacar o papel da Rede pela Humanização do Parto e Nascimento (ReHuNa). A organização, que atua desde 1993, tem como principal objetivo a "divulgação de assistência e cuidados perinatais com base em evidências 
científicas e em conformidade com as recomendações da Organização Mundial da Saúde". A ReHuNa, durante sua atuação, já promoveu diversos eventos científicos, campanhas e outras ações para promover seus ideais de humanização. (28)

Em relação aos desafios implicados para a implantação da proposta de humanização do parto dentro de determinadas instituições, Busanello e colaboradores (29) concluem seu estudo recomendando que, para iniciar este processo de reflexão e transformações no âmbito da
assistência à parturição, seja necessário compreender que o significado de
humanizar envolve os aspectos mais subjetivos do ser humano. Para tanto,
não se deve esperar apenas uma mudança na postura dos trabalhadores,
mas também em todas as relações interpessoais existentes neste contexto.
As condições dignas de trabalho, a valorização, a capacitação e a
sensibilização dos trabalhadores da saúde, são meios de fazer com que
estes se sintam humanizados e, assim, entendam a importância de
humanizar. (29)

O movimento pela humanização aparece, segundo Diniz (17), como uma "necessária redefinição das relações humanas na assistência" e inclui a compreensão da condição humana e dos direitos humanos. Dentre os vários sentidos por ela descritos, e antagonizados aos conceitos de violência obstétrica, pode-se destacar sua relação com uma assistência baseada em evidências, o redimensionamento dos papéis e poderes no parto, a participação da parturiente nas decisões, as possibilidades de alívio da dor e uma assistência baseada nos direitos (humanos, das mulheres).

\subsubsection{Referenciais a serem utilizados na assistência ao parto}

A White Ribbon Alliance, organização que defende a maternidade segura, elaborou uma carta sobre cuidado respeitoso na maternidade, baseado em diversos documentos, pactos e legislações - nacionais e internacionais. $\mathrm{O}$ documento aponta alguns dos que configurariam direitos humanos das mulheres antes, durante e após o parto. Dentre outros, o material destaca o direito a estar livre de maus tratos, à 
informação, consentimento e recusa de tratamento, o direito à privacidade e confidencialidade, bem como a ser tratada com dignidade e respeito (30).

Por outro lado, conforme referido anteriormente, a adoção das boas práticas no parto e nascimento divulgadas pela OMS (31) configura uma importante estratégia para garantia da qualidade da assistência ao parto. Com procedimentos baseados em evidências científicas, que resguardam o saber técnico como princípio ético da prática obstétrica, o relatório, elaborado por um grupo de especialistas internacionais, traz uma série de recomendações para o atendimento ao parto normal. Esse material classifica os procedimentos de rotina em quatro categorias:

A. Condutas que são claramente úteis e que devem ser encorajadas, tais como o respeito à privacidade da mulher, respeito à escolha do acompanhante, utilização do plano de parto, a liberdade de posição e movimento durante o trabalho de parto, dentre outros;

B. Condutas claramente prejudiciais ou ineficazes e que deveriam ser eliminadas, tais como o uso rotineiro de enema (lavagem intestinal) e da tricotomia (raspagem dos pelos), a infusão intravenosa rotineira e outras mais;

C. Condutas sem evidência suficiente e que devem ser usadas com precaução, tais como clampeamento precoce do cordão umbilical, utilização de ocitocina rotineira, manipulação ativa do feto no momento do nacimento, dentre outros;

D. Condutas frequentemente usadas de modo inaproriado, tais como o controle da dor através de anestesia, a restrição de comidas e líquidos durante o trabalho de parto, cesarianas e uso rotineiro de episiotomia (corte na região vaginal) e outros procedimentos.

No âmbito nacional, foi instituída em 2011 a Rede Cegonha, buscando "assegurar à mulher o direito ao planejamento reprodutivo e à atenção humanizada à gravidez, ao parto e ao puerpério" (32). Dentre os seus objetivos, há que se destacar o de fomentar a implantação de um novo modelo de atenção à saúde da mulher e à saúde da criança, por meio de princípios como "o respeito, a proteção e a 
realização dos direitos humanos", "respeito à diversidade cultural, étnica e racial" e "promoção da equidade", dentre outros.

Uma assistência ao parto digna e respeitosa pode ser embasada por esses documentos e políticas, dentre outros diversos. Entretanto, para além de normativas e protocolos, é preciso uma mudança de paradigma no que se refere ao atendimento prestado às gestantes e puérperas por parte dos profissionais e instituições de saúde. 


\subsection{A BIOÉTICA}

A homologação, em 2005, da Declaração Universal sobre Bioética e Direitos Humanos (8) pela Organização das Nações Unidas para a Educação, a Ciência e a Cultura (UNESCO), representa um marco conceitual para a Bioética. A declaração "trata das questões éticas relacionadas à medicina, às ciências da vida e às tecnologias associadas quando aplicadas aos seres humanos, levando em conta suas dimensões sociais, legais e ambientais".

Composta por 15 princípios complementares e inter-relacionados, eles podem ser classificados, segundo Oliveira (33), enquanto:

i: princípios relativos à pessoa humana: dignidade humana e direitos humanos; beneficência e não maleficência; autonomia e responsabilidade individual; consentimento; respeito pela vulnerabilidade humana e integridade pessoal; privacidade e confidencialidade;

ii. princípios sociais: igualdade, justiça e equidade; não discriminação e não estigmatização; respeito pela diversidade cultural e pluralismo; solidariedade e cooperação, responsabilidade social e saúde; partilha de benefícios;

iii. princípios ambientais: proteção das gerações futuras; proteção do meio ambiente, da biosfera e da biodiversidade. (33)

Conforme pontua Adorno (34), os princípios são descritos na declaração sem que haja definição precisa de seu significado. $O$ autor atribui isso à impossibilidade de consenso global sobre o significado preciso de alguns termos, possibilitando um equilíbrio entre o universalismo das normas bioéticas e o respeito à diversidade cultural na interpretação do documento e configurando "an important step in the search for global bioethical Standards" (34).

Compondo os objetivos da declaração, destaca-se a propositura de "prover uma estrutura universal de princípios e procedimentos para orientar os Estados na formulação de sua legislação, políticas ou outros instrumentos no campo da bioética", assim como "orientar as ações individuais de grupos, comunidades, instituições e empresas públicas e privadas"(8). Em consonância com a proposta do documento, optou-se pela utilização deste referencial para enquanto norte ético para discutir as ações desenvolvidas dentro da temática da assistência obstétrica.

Neste capítulo, para facilitar a conceituação e aplicação à temática proposta, os princípios "consentimento" e "indivíduos sem capacidade para consentir" foram 
abordados em conjunto. A discussão se deu conforme sequência apresentada na DUBDH (8), sendo que os artigos de 13 a 17 não serão detalhados, por não se adequarem à discussão proposta pelo presente trabalho. A discussão e interpretação dos princípios constantes na Declaração foram realizadas por meio de referenciais nacionais - possibilitando o recorte à luz da bioética brasileira, uma vez que a perspectiva desses autores permite uma melhor aproximação com o tema e contexto apresentados.

\subsubsection{Dignidade Humana e Direitos Humanos}

As atrocidades cometidas durante a Segunda Guerra Mundial constituíram elemento propulsor às discussões sobre os direitos humanos e a bioética. Os primeiros documentos de alcance mundial, que configuram marco histórico nessas duas áreas, surgiram em resposta a essas barbáries - a saber, o Código de Nuremberg, que define os primeiros parâmetros para pesquisa com seres humanos, e a Declaração Universal de Direitos Humanos, datados de 1949 e 1948, respectivamente.

Oliveira (33) defende a dignidade como sendo o principal ponto de contato entre a bioética e os direitos humanos, sendo que ambos "surgem como formas de assegurar determinados valores e de proteger a pessoa humana, reconhecendo-Ihe uma dignidade inerente". A autora sustenta ainda que, no âmbito da Bioética, devemos trazer a dignidade "como limite, que impõe à sociedade, ao Estado e à própria pessoa um dever de não coisificá-la" (33) - o que comumente acontece no modelo biomédico e na sociedade atual.

A dignidade humana, embora basilar no contexto da DUBDH e da defesa dos direitos rumanos, configura um dos princípios mais desafiadores de se definir. Segundo Godoi e Garrafa (35), isso ocorre pois, embora se pretenda a dignidade enquanto valor universal, sua definição está atrelada a fatores históricos e sociais o que implica em uma diversidade de entendimentos. Para os autores, "a dignidade humana pressupõe o respeito pelo outro, pela pluralidade e pela diversidade humana“(35) e sua defesa deve ser imperativa. 
A violência obstétrica, enquanto violência contra a mulher, já caracteriza em si uma violação aos direitos humanos. Considerando a perspectiva específica, no rol desses direitos, de estar livre de tratamentos cruéis, humilhantes e degradantes, é possível fazer aproximações em relação à categoria de abuso físico, dentro da violência obstétrica, como a utilização de procedimentos sem justificativa clínica como a imobilização física em posições dolorosas. $O$ desrespeito às escolhas da mulher sobre o seu processo de parto, configuram uma violação ao direito reprodutivo.

\subsubsection{Benefício e Dano}

As concepções de benefício e de dano fazem parte do métier das discussões em Filosofia e posteriormente em Direito. Canonicamente, compõem o juramento hipocrático. Na Bioética, a inserção do tema se deu por meio da teoria principialista (36), na qual os mesmo princípios receberam a designação de princípios de beneficência e de não maleficência. De maneira simplificada, a princípio da beneficência implicava em uma "exigência de ação" (fazer o bem), enquanto a princípio da não maleficência refletia uma "proibição de ação" (não fazer o mal).

Contudo, no contexto da DUBDH a noção de "benefício e dano" foi incorporada como um princípio único, estabelecendo que:

Os benefícios diretos e indiretos a pacientes, sujeitos de pesquisa e outros
indivíduos afetados devem ser maximizados e qualquer dano possível a tais
indivíduos deve ser minimizado, quando se trate da aplicação e do avanço
do conhecimento científico, das práticas médicas e tecnologias associadas.

Sua aplicação gera controvérsias, uma vez que a minimização do dano e maximização do benefício são critérios relativizáveis e dependem da interpretação individual de cada caso, segundo algumas escolas de pensamento bioético. Paranhos, Garrafa e Melo (37) denunciam a flexibilização na interpretação desses princípios em diversas pesquisas com seres humanos, expondo justamente os mais vulneráveis, "intensificando assim os benefícios que lhes são devidos e os riscos de danos a que estão potencialmente expostos" (37). 
Um exemplo clássico para aplicação desse princípio no contexto da atenção ao parto está na prática da episiotomia. O procedimento consiste em realizar um corte no períneo objetivando "evitar laceração" durante a passagem do bebê. Há que se considerar a possibilidade de intervenções de caráter iatrogênico, portanto, a avaliação criteriosa dos benefícios e danos deveria ser imperativa nesse processo.

\subsubsection{Autonomia e Responsabilidade Individual}

A autonomia tem origem na expressão grega autos, que significa "mesmo", e nomos, que se traduz por "lei", "regra", "governo", indicando, portanto, a noção de "autogoverno". A autonomia é, portanto, a capacidade de decidir e agir tendo em vista o que é melhor para si (38). Esta concepção é configurada num princípio central da Bioética principialista, pautada no indivíduo, que é o Princípio de Respeito pela Autonomia.

Albuquerque e Garrafa (39) apontam que o Princípio da Respeito pela Autonomia acontece por meio de duas condições essenciais: a existência de liberdade e a qualidade de agente, i.e., a possibilidade de agir. A ausência de forças coercitivas e influências controladoras determinariam a liberdade de escolha, "ou seja, num contexto clínico, os profissionais envolvidos na assistência não devem impor condições ou exercer influências quanto à decisão do indivíduo" (39). Para que haja ação intencional, é necessário que se acesse as informações e opções existentes à situação - configurando obrigação do profissional/pesquisar de fornecêlas, num contexto clínico - para efetivamente garantir a autonomia da escolha.

Embora configure um dos princípios bioéticos mais disseminados e reconhecidos, Garrafa, Martorell e Nascimento (40) apontam para os perigos da supervalorização da autonomia. Além dos riscos de se "anular qualquer visão inversa, coletiva e indispensável ao enfrentamento das tremendas injustiças relacionadas com a exclusão social" (41), seus instrumentos podem ser utilizados como uma forma de isenção dos profissionais/pesquisadores em relação à decisão individual do sujeito(40). Os autores questionam 
a quem caberia o papel de promover a ação pedagógica de fortalecimento da autonomia. Afinal, haveria uma possibilidade de influência imoral para inclinar a decisão do outro, podendo se aproximar de uma abordagem paternalista ou autoritária. Ainda sobre a autonomia, evidenciam a falta de clareza de aplicação do princípio, o que poderia trazer possibilidades de posições flexíveis diante da capacidade de exercer autonomia. (40)

O respeito à autonomia da mulher está implicado em todo contexto da assistência à saúde. Sua promoção se dá através do fornecimento de informação acessível e de qualidade e a respeito das alternativas possíveis, bem como o respeito às escolhas decorrentes desse processo. No que se refere à assistência ao parto e nascimento, o plano de parto pode ser considerado um instrumento de respeito à autonomia da mulher, uma vez que sua construção está relacionada à livre escolha da gestante - baseada em informações previamente recebidas sobre as possibilidades existentes para a assistência ao parto.

\subsubsection{Consentimento e indivíduos sem a capacidade para consentir}

O consentimento é utilizado no contexto da prática clínica e pesquisa com seres humanos e é considerado $O$ instrumento que concretiza 0 respeito à autonomia do indivíduo. Afinal, para que haja a formalização do consentimento, é preciso garantir que a pessoa "é competente para agir, tem acesso à informação e a compreende, atua voluntariamente e, por fim, consente com a intervenção" (42).

Conforme previsto na DUBDH, qualquer intervenção médica ou pesquisa científica só deve ser realizada com "o consentimento prévio, livre e esclarecido do indivíduo envolvido". O consentimento deve ser baseado em informações adequadas e fornecidas de maneira compreensível, sendo que o mesmo "pode ser retirado pelo indivíduo a qualquer momento e por qualquer razão, sem acarretar desvantagem ou preconceito" (8).

Entretanto, alguns autores (40-43) criticam a utilização do consentimento como instrumento para proteção dos pesquisadores e profissionais de saúde, conforme explicado por Oliveira (43):

O fato de que o consentimento informado é uma determinação legal ou institucional e que sua mera subscrição consiste no cumprimento das normativas que o prescreveram altera completamente a ideia de que deve expressar necessariamente a autodeterminação do paciente. Desse modo, 
a relação profissional de saúde, notadamente médico e paciente, passou a ser baseada na ideia privatista de contrato entre partes, o qual se formaliza mediante $\mathrm{o}$ termo de consentimento informado. Subsequentemente, 0 consentimento informado deixa de ser a materialização da autonomia do paciente e passa a ser uma peça jurídica apta a impedir ações judiciais. $\mathrm{O}$ receio de ser acionado judicialmente por parte do médico e a do paciente de ter seus direitos violados passou a reger a subscrição dos termos de consentimento informado. (41)

De acordo com Hostiuc (42), para que o consentimento informado seja válido no contexto clínico, é necessário que cinco requisitos estejam presentes, a saber: o paciente esteja informado; entenda a informação; aja por vontade própria; tenha competência legal; autorize o procedimento. Nos casos em que os indivíduos não possuam capacidade legal de fornecer o seu consentimento, deve ser garantida proteção especial - conforme previsto na DUBDH (8).

Mesmo nos casos em que o consentimento seja fornecido pelo responsável legal, a autorização deve "ser obtida no melhor interesse do indivíduo (...) [que] deve ser envolvido, na medida do possível, tanto no processo de decisão sobre consentimento assim como sua retirada" (8).

A elaboração do plano individual de atendimento, comumente conhecido como plano de parto, constitui conduta a ser encorajada, conforme a OMS (31). Esse material tem como objetivo orientar os profissionais e/ou instituição sobre as escolhas da mulher em relação ao processo de parto. O plano deve ser construído com base em informações, de qualidade, obtidas pela mulher durante a gestação e o pré-natal e expresso por escrito - constituindo uma formalização do consentimento informado da mulher neste contexto.

\subsubsection{Respeito pela Vulnerabilidade Humana e pela Integridade Individual}

Cunha e Garrafa (44) defendem o conceito de vulnerabilidade como princípiochave e fundamental para a Bioética global. Entretanto, os autores defendem não ser possível uma definição "concreta" universal, pois há que se levar em consideração que a discussão é dinâmica e deve respeitar as diferentes perspectivas regionais. 
Relatório produzido pelo International Bioethics Committee of UNESCO (IBC) sobre a vulnerabilidade, aponta que, "in its first and more general sense, is an essential feature of human nature" (45). Todo ser humano está exposto a um risco permanente de ter a sua integridade individual ferida, sendo, portanto, vulnerável. Entretanto, a vulnerabilidade a ser protegida, conforme preconizado na DUBDH, é aquela a que estão expostos determinados grupos e indivíduos - podendo a vulnerabilidade ser situacional ou ser fruto dos determinantes sociais (45).

Schramm (46) propõe a utilização de nomenclaturas diferentes para explicar os aspectos variados da vulnerabilidade:

De fato, se todos são potencialmente (ou virtualmente?) vulneráveis enquanto seres vivos, nem todos são vulnerados concretamente devido a contingências como o pertencimento a uma determinada classe social, a uma determinada etnia, a um dos gêneros ou dependendo de suas condições de vida, inclusive seu estado de saúde. Em suma, parece razoável considerar mais correto distinguir a mera vulnerabilidade da efetiva "vulneração", vendo a primeira como mera potencialidade e a segunda como uma situação de fato, pois isso tem conseqüências relevantes no momento da tomada de decisão. (46)

Portanto, todas as gestantes e puérperas estão naturalmente inseridas dentro de grupos vulneráveis - tanto devido ao gênero feminino quanto à condição de paciente. Ambas as características as colocam em um papel social considerado hierarquicamente inferior à autoridade médica/profissional, que constituem os detentores do conhecimento e titulares do processo de atenção ao parto. (47)

\subsubsection{Privacidade e Confidencialidade}

Está disposto na DUBDH que "a privacidade dos indivíduos envolvidos e a confidencialidade de suas informações devem ser respeitadas", bem como tais informações "não devem ser usadas ou reveladas para outros propósitos que não aqueles para os quais foram coletadas ou consentidas" (8).

Francisconi e Goldim (48) definem a privacidade como "a limitação do acesso às informações de uma dada pessoa, bem como do acesso à própria pessoa e à sua intimidade". Por sua vez, a confidencialidade garante a preservação da privacidade, isto é, protege a divulgação de informações a quem não tem a necessidade de conhecê-las (49). Para os autores, a quebra de privacidade "consiste no acesso 
desnecessário ou uso de informações sem a devida autorização", enquanto a quebra de confidencialidade pode ser distinguida como "a ação de revelar ou deixar revelar informações fornecidas em confiança" (48).

A garantia da proteção à privacidade e confidencialidade dos indivíduos deve ser um esforço conjunto dos profissionais e da instituição de saúde. Nesse sentido, Cunha e Patrício (50) alertam para os riscos inerentes à utilização das novas tecnologias da informação no cotidiano dos serviços de saúde, bem como reforçam o papel das instituições na manutenção de sistemas de proteção seguros aos documentos que contenham informações de pacientes. A privacidade do paciente está relacionada ao seu direito de escolha, que por sua vez decorre da expressão de sua autonomia.

Dentro da perspectiva de atenção ao parto, o respeito à privacidade envolve a proteção da imagem e da intimidade da mulher. Neste aspecto, as condições estruturais e práticas institucionais (como hospitais-escola) costumam apresentar os principais obstáculos à preservação da mulher. (51)

\subsubsection{Igualdade, Justiça e Equidade}

A DUBDH (8) assevera que "A igualdade fundamental entre todos os seres humanos em termos de dignidade e de direitos deve ser respeitada de modo que todos sejam tratados de forma justa e equitativa".

Para Azevedo (52), a Igualdade, disseminada pelos ideais da Revolução Francesa, refere-se inicialmente à igualdade de direitos, pois todos seriam iguais perante a lei. Entretanto, ao se desconsiderar a diversidade e as diferenças entre os indivíduos a desigualdade seria perpetuada. Essa seria, portanto, a base crítica para fundamentar um princípio de equidade: "o reconhecimento de necessidades diferentes, de sujeitos também diferentes, para atingir direitos iguais” (53). Corgozinho e Oliveira (54) defendem a utilização da equidade enquanto marco ético para a análise de temas bioéticos na saúde pública. 
De acordo com a teoria da justiça de Rawls (55), deve haver uma igualdade de oportunidade para todos e, para isso, aos indivíduos menos privilegiados da sociedade é que devem ser repassados, preferencialmente, os benefícios sociais.

$\mathrm{Na}$ associação entre esses três conceitos, pode-se dizer que a equidade é o ponto de partida, a igualdade é a linha de chegada e a justiça (social) é o caminho. Pois somente "através do reconhecimento das diferenças e das necessidades diversas dos sujeitos sociais que se pode alcançar a igualdade" (53).

O reconhecimento dessas diferenças e a necessidade de uma proteção especial dedicada às mulheres, gestantes e puérperas constituem a base da construção de políticas específicas para atenção à saúde desses grupos - tais como a Política Nacional de Humanização e a Rede Cegonha, já citadas anteriormente.

\subsubsection{Não discriminação e não estigmatização}

Segundo a DUBDH, "Nenhum indivíduo ou grupo deve ser discriminado ou estigmatizado por qualquer razão, o que constitui violação à dignidade humana, aos direitos humanos e liberdades fundamentais" (8).

Godoi e Garrafa (35) "fenômenos como etnocentrismo, racismo, xenofobia, sexismo e homofobia, como consequência da intolerância diante das diferenças", ganharam maior amplitude e visibilidade como fruto do processo de globalização massiva e imposição de novas formas de convivência entre diferentes grupos e culturas. Para os autores, o estigma se revela no processo de inferiorização do outro, eliminando a sua dignidade e gerando a discriminação; a discriminação, por sua vez, é parte inerente do estigma e traz desvantagem social à pessoa ou grupo estigmatizado. Esses dois processos são considerados produtos sociais que reproduzem desigualdades sociais e estruturais (35).

O Relatório do IBC-UNESCO (56) sobre esse princípio aponta que decisões ou práticas discriminatórias configuram violação dos direitos fundamentais - como os direitos humanos e a dignidade humana - e são censuráveis. 
Diniz e colaboradores (57) registraram que houve, na última década, diminuição das disparidades raciais - que desfavoreciam mulheres negras - no que se refere à assistência prestada durante o pré natal e o parto. Apesar disso, persistem diferenças relevantes em relação ao acesso e qualidade da assistência prestada, tais como um menor número de consultas no pré natal e maior vulnerabilidade à violência obstétrica.

\subsubsection{Respeito pela Diversidade Cultural e pelo Pluralismo}

Lorenzo (58) defende que, no processo de interação entre indivíduos, é essencial que os envolvidos possam se manifestar de acordo com seus preceitos e que haja uma articulação entre eles, possibilitando o respeito às crenças e às tradições de cada sujeito.

A DUBDH destaca a importância do respeito pela diversidade cultural e pluralismo, mas alerta que "tais considerações não devem ser invocadas para violar a dignidade humana, os direitos humanos e as liberdades fundamentais nem os princípios dispostos nesta Declaração“ (8). Em consonância com o disposto na declaração, Albuquerque (59) defende a incorporação dos direitos humanos como limite e referencial aos conflitos bioéticos que envolvem a interculturalidade. A promoção do respeito às diferentes culturas, quando houver contextos culturais diferentes, deve ocorrer sem que haja violações de direitos.

Por outro lado, Feitosa e Nascimento (60) destacam que os direitos humanos não conseguem atender à especificidade cultural ou particularidade do contexto social de diferentes povos e subconjuntos da população. Os autores alertam que,

Ao estabelecer padrões do que sejam as necessidades intrínsecas à qualidade de vida para todos os seres humanos, que possam ser aplicados pelos governos nacionais a distintas realidades, os $\mathrm{DH}$ permitem indiretamente a manutenção da assimetria social que estrutura a dinâmica dessas mesmas sociedades. Dado que são por natureza incapazes de impedir a reprodução de assimetrias na dinâmica interna dessas sociedades, sua aplicação não inibe a imposição de parâmetros que ignoram diferenças, especialmente as de cunho cultural, sobrepondo indiscriminadamente os valores da maioria. (60) 
Ao longo dos mais de 35 anos de existência, a Bioética se configura como um dos campos da ética aplicada que mais avançou, tendo como um dos referenciais básicos que sustenta a sua epistemologia o respeito ao pluralismo. Existem, portanto, diversas teorias bioéticas que permitem várias possibilidades de interpretação e aplicação. No presente trabalho, a discussão pautada pela Declaração Universal sobre Bioética e Direitos Humanos foi proposta visando permitir a aproximação com uma perspectiva bioética pautada na realidade brasileira, possibilitando melhor adequação à temática. 


\section{OBJETIVOS}

\subsection{OBJETIVO GERAL}

Conhecer a percepção dos estudantes da área da saúde sobre a violência obstétrica e sua relação com uma perspectiva bioética pautada nos princípios previstos na Declaração Universal sobre Bioética e Direitos Humanos.

\subsection{OBJETIVOS ESPECÍFICOS}

i. Identificar o conhecimento e vivências dos estudantes da área da saúde sobre a violência obstétrica.

ii. Verificar o conhecimento sobre a bioética entre estudantes da área da saúde.

iii. Identificar diferenças percebidas pelos estudantes entre a teoria e a prática.

iv. Discutir possível relação entre o desrespeito aos princípios bioéticos, presentes na Declaração Universal sobre Bioética e Direitos Humanos, e a ocorrência de violência obstétrica. 


\section{MÉTODO}

Realizou-se pesquisa exploratória, objetivando "proporcionar maior familiaridade com o problema, com vistas a tomá-lo mais explícito ou a constituir hipóteses", conforme descrito por Gil (61). Para tanto, foi utilizada abordagem qualitativa visando elucidação de conceitos e experiências a respeito do tema e a exposição de um relato de caso, que caracteriza parte do material coletado.

\subsection{PARTICIPANTES/SUJEITOS}

Os sujeitos da pesquisa foram estudantes da área de saúde, em todos os níveis de formação que consentiram com a utilização das informações fornecidas para a pesquisa acadêmica em curso - autorização que se deu por meio do preenchimento e envio do formulário, conforme explicação contida no instrumento. Houve o preenchimento de 111 questionários, dos quais 09 foram desconsiderados uma vez que os sujeitos que não se enquadravam nestes critérios estabelecidos.

\subsection{INSTRUMENTO DE PESQUISA}

O instrumento utilizado foi o questionário estruturado, elaborado pela autora, composto por cinco sessões que continham questões abertas e fechadas e disponibilizado por meio eletrônico.

A primeira sessão foi composta de questões sociodemográficas visando caracterização da amostra. As demais sessões tinham como objetivo coletar informações sobre o conhecimento, opinião e vivência dos participantes sobre a violência obstétrica e a Bioética. A sessão de número três foi disponibilizada apenas àqueles que responderam afirmativamente sobre a ocorrência de violência obstétrica (consigo ou terceiro), para que detalhassem a experiência.

Com exceção da sessão de número três, conforme já explicitado, e de um espaço final para observações - caso fosse da vontade do participante - todas as 
perguntas eram de preenchimento obrigatório. Esse procedimento foi adotado para mitigar a existência de lacunas nas respostas, sendo assim, os formulários que não estivessem com os dados solicitados completamente preenchidos tiveram sua submissão impedida.

\subsection{PROCEDIMENTO DE COLETA DE DADOS}

Para captação dos participantes utilizou-se a técnica "snowboll sampling", através do acesso a indivíduos e grupos-chave para a divulgação da pesquisa (62). A estes, foi enviado por meios eletrônicos (E-mail, Facebook e Whatsapp), mensagem-convite de participação contendo o link para preenchimento do questionário, explicação sobre o teor - e público alvo - da pesquisa e meios de contato com a pesquisadora.

A ferramenta "Formulários Google" foi utilizada para a elaboração do questionário, constante no Anexo $\mathrm{A}$, e a coleta dos dados dele resultantes, possibilitando a garantia de total privacidade e confidencialidade aos participantes. $O$ questionário esteve disponível para preenchimento entre dezembro/2016 e janeiro/2017.

\subsection{ANÁLISE DE DADOS}

Os dados para caracterização da amostra foram organizados e analisados através do programa Excel, utilizado para o cálculo de percentual simples e elaboração de tabelas.

As respostas às questões abertas foram analisadas por meio da análise de conteúdo. Conforme os passos descritos por Bardin (63), antes da análise foi realizada leitura flutuante das respostas para identificação de categorias; posteriormente o material foi explorado e codificado e, por fim, os resultados foram tratados e interpretados em consonância com o objetivo da pesquisa. 
Ao final da etapa descritiva, os achados foram discutidos baseados nos pressupostos teóricos da pesquisa, que teve como referencial bioético a Declaração Universal sobre Bioética e Direitos Humanos. Por fim, foi apresentado um relato de caso, que emergiu da fala dos participantes, como forma de caracterização dos achados da pesquisa.

\subsection{ASPECTOS ÉTICOS}

Por se tratar de pesquisa que envolve seres humanos, o projeto de pesquisa foi submetido à análise do Comitê de Ética da Faculdade de Ciências da Saúde de Universidade de Brasília, conforme legislação vigente no país (64) e foi aprovado em novembro de 2016, por meio do parecer ํㅜ 1.847.272 - disponível no Anexo A. 


\section{RESULTADOS E DISCUSSÃO}

\subsection{CARACTERIZAÇÃO DA AMOSTRA}

Para embasar a pesquisa, os dados foram coletados por meio de questionário estruturado, disponibilizado por meio eletrônico através da técnica snowball sampling, conforme detalhado na metodologia. Houve o preenchimento de 111 formulários, dentre os quais nove não se enquadravam nos critérios de inclusão da pesquisa - estudantes da área da saúde - e foram desconsiderados da estatística. A primeira parte do questionário foi composta por questões que objetivavam a caracterização da amostra, com dados sociodemográficos e acadêmicos, cujos resultados estão representados nas Tabelas 1, 2 e 3.

Tabela 1 - Características sociodemográficas da amostra

\begin{tabular}{|c|c|c|c|}
\hline \multicolumn{2}{|c|}{ DADOS SOCIODEMOGRÁFICOS } & $\mathbf{N}$ & $\%$ \\
\hline IDADE & $\begin{array}{l}\text { Menor de } 20 \text { anos } \\
20 \text { a } 25 \text { anos } \\
26 \text { a } 30 \text { anos } \\
31 \text { a } 35 \text { anos } \\
36 \text { a } 40 \text { anos } \\
41 \text { a } 45 \text { anos } \\
46 \text { ou mais }\end{array}$ & $\begin{array}{l}09 \\
62 \\
16 \\
08 \\
02 \\
01 \\
04\end{array}$ & $\begin{array}{c}8,8 \% \\
60,8 \% \\
15,7 \% \\
7,8 \% \\
2 \% \\
1 \% \\
3,9 \%\end{array}$ \\
\hline SEXO & $\begin{array}{l}\text { Feminino } \\
\text { Masculino }\end{array}$ & $\begin{array}{l}92 \\
10\end{array}$ & $\begin{array}{c}90,2 \% \\
9,8 \%\end{array}$ \\
\hline NATURALIDADE & $\begin{array}{c}\text { DF } \\
\text { AL } \\
\text { MG } \\
\text { RJ } \\
\text { BA } \\
\text { CE } \\
\text { GO } \\
\text { PE } \\
\text { AM } \\
\text { PB } \\
\text { MA }\end{array}$ & $\begin{array}{l}68 \\
14 \\
04 \\
03 \\
03 \\
02 \\
04 \\
01 \\
01 \\
01 \\
01\end{array}$ & $\begin{array}{c}66,7 \% \\
13,7 \% \\
3,9 \% \\
2,9 \% \\
2,9 \% \\
2 \% \\
3,9 \% \\
1 \% \\
1 \% \\
1 \% \\
1 \%\end{array}$ \\
\hline FILHOS & $\begin{array}{l}\text { NÃO } \\
\text { SIM }\end{array}$ & $\begin{array}{l}71 \\
31\end{array}$ & $\begin{array}{l}69 \% \\
31 \%\end{array}$ \\
\hline
\end{tabular}

Fonte: autora. 
Conforme apresentado na Tabela 1, a amostra foi majoritariamente composta por participantes do sexo feminino, com idade de até 25 anos, naturais do Distrito Federal e que não possuem filhos. A segunda faixa etária mais presente está situada entre 26 a 30 anos, havendo apenas 14,7\% de participação de indivíduos na faixa acima dos 30 anos. Em relação à naturalidade dos participantes, a segunda região com maior predominância foi a Nordeste, com destaque para o estado de Alagoas, enquanto a região Sul foi a única do país não representada na amostra.

Por se tratar de estudo exploratório, com amostra pequena, não é possível fazer muitas inferências em relação ao perfil dos participantes e suas variáveis. Entretanto, a predominância de respondentes do sexo feminino está em consonância com levantamento do Instituto Nacional de Estudos e Pesquisas (INEP), que revelou a preponderância do sexo feminino em cursos de nível superior na área da saúde (65).

Apresentada abaixo, a Tabela 2 traz informações sobre a espiritualidade dos participantes e, embora configure um dado sociodemográfico, está apresentada de maneira separada, uma vez que se tratava de questão aberta - visando permitir maior completude de respostas dentro do rol de possíveis declarações de crenças.

Tabela 2 - Credo confessional representado na amostra

\begin{tabular}{cccc}
\hline Auto declaração & $\mathbf{N}$ & $\%$ & Classificação da autora \\
\hline Adventista & 01 & $1 \%$ & \\
Católica & 47 & $46,1 \%$ & \\
Cristão & 06 & $5,9 \%$ & Cristão $(69,6 \%)$ \\
Cristão protestante & 05 & $4,9 \%$ & \\
Evangélica & 12 & $11,7 \%$ & Não declarada (11,7\%) \\
Não declarada/Ausente & 12 & $11,7 \%$ & Espírita $(6,8 \%)$ \\
Espírita & 07 & $6,8 \%$ & Agnóstico (3\%) \\
Agnóstico & 02 & $2 \%$ & Ateu (3\%) \\
Agnóstico Ateísta & 01 & $1 \%$ & \\
Ateu & 03 & $3 \%$ & Outras crenças (3\%) \\
Umbanda & 01 & $1 \%$ & \\
Deísta & 01 & $1 \%$ & Crê em Deus (1\%) \\
Indu & 01 & $1 \%$ & Preenchimento incorreto (2\%) \\
Crê em Deus & 01 & $1 \%$ &
\end{tabular}

Fonte: autora.

As auto declarações estão presentes na tabela, objetivando manter as particularidades de cada informação, bem como uma classificação geral promovida pela autora para facilitar a análise. Houve, no contexto da amostra, maior 
prevalência na categoria cristã, seguida por ausência de declaração e espíritas. Os agnósticos, ateus e outras crenças representam 9\% da amostra e há, ainda, um pequeno percentual em que houve preenchimento incorreto da informação possivelmente por erro de leitura/interpretação da questão.

Em relação às informações acadêmicas, apresentadas na Tabela 3, a maioria dos participantes informou estudar em instituição pública de ensino, ser da área de enfermagem e estar cursando a graduação. Cerca de 1/5 da amostra corresponde a estudantes de Medicina.

Tabela 3 - Características acadêmicas da amostra

\begin{tabular}{cccc}
\hline \multicolumn{2}{c}{ DADOS ACADÊMICOS } & N & $\%$ \\
\hline & Enfermagem & 61 & $59,8 \%$ \\
Farmácia & 07 & $6,9 \%$ \\
ÁREA DE & Fisioterapia & 08 & $7,8 \%$ \\
FORMAÇÃO & Medicina & 20 & $19,6 \%$ \\
& Nutrição & 02 & $2 \%$ \\
& Psicologia & 03 & $2,9 \%$ \\
& Terapia Ocupacional & 01 & $1 \%$ \\
INSTITUIÇÃO DE & & & $63,7 \%$ \\
ENSINO & Pública & 65 & $36,3 \%$ \\
& Privada & 37 & $65,7 \%$ \\
GRAU DE & & & $15,7 \%$ \\
INSTRUÇÃOO & Graduação & 67 & $5,9 \%$ \\
& Especialização & 16 & $8,8 \%$ \\
& Residência & 06 & $3,9 \%$ \\
\hline
\end{tabular}

Fonte: autora.

Embora não haja informações concretas sobre a vivência acadêmica e profissional dos participantes, a maior representação entre os cursos da área de enfermagem e medicina pode ser explicada devido à temática da pesquisa estar relacionada à área de saúde da mulher/obstetrícia, que configura disciplina específica obrigatória em ambos os cursos, além de serem esses os profissionais responsáveis pela atenção ao parto e nascimento. 


\subsection{VIOLÊNCIA OBSTÉTRICA}

A segunda parte do questionário englobou basicamente questões abertas e de múltipla escolha sobre conhecimento, percepção e familiaridade dos paticipantes com as temáticas da violência obstétrica e bioética. $O$ roteiro de perguntas foi elaborado buscando a coerência e continuidade do assunto, e as questões de múltipla escolha foram dispostas ao final, de modo a evitar a indução das respostas.

\subsubsection{Percepção e conhecimento dos estudantes sobre a violência obstétrica}

Ao serem questionados sobre o seu entendimento sobre violência obstétrica, praticamente todos os participantes citaram, dentre outros, ofensas físicas e psicológicas à gestante durante o processo de parto. Aspectos relacionados a procedimentos desnecessários, praticados sem autorização ou autorizados com base em informações imprecisas também receberam diversas menções. Alguns trechos de respostas que demonstram essas e demais questões, conforme apresentado no Quadro 1.

A fala dos participantes está em consonância com a literatura disponível sobre o assunto, inclusive o enfoque dado às questões técnicas na tentativa de conceituação do termo. Em se tratando das categorias de violência obstétrica propostas por Bowser e Hill (19), e citadas em outros textos (2,66-68), as descrições fornecidas pelos participantes se enquadram, majoritariamente, em "abuso físico" e "cuidado não consentido" - em especial quando se referem a procedimentos como a episiotomia, utilização de ocitocina, privação de movimento e manobra de Kristeller, que são praticados sem indicação e/ou consentimento.

Pode-se dizer que violência obstétrica é aquela vivida no momento da gestação, parto, nascimento e pós-parto. Caracterizada, dentre outros, por agressão física, psicológica, verbal, simbólica e sexual, assim como pela negligência na assistência e pela discriminação (69). Também podem ser consideradas como violência obstétrica condutas médicas excessivas ou inapropriadas, adesão a 
práticas obstétricas reconhecidamente desaconselhadas, muitas vezes prejudiciais e sem embasamento em evidências científicas e impedimento da presença de acompanhantes de livre escolha da gestante durante o parto (1).

Quadro 1: Caracterização da violência obstétrica, pelos estudantes

\begin{tabular}{|c|c|c|}
\hline tação & s & nia \\
\hline $\begin{array}{l}\text { "São todos os } \\
\text { procedimentos }[\ldots] \text { que } \\
\text { não são preconizados } \\
\text { pelos princípios da } \\
\text { humanização, do cuidado } \\
\text { e nas evidências } \\
\text { científicas." }\end{array}$ & $\begin{array}{l}\text { "Ato de qualquer natureza } \\
\text { que implique das omissões } \\
\text { dos direitos da parturiente. } \\
\text { Ex: kristeller, privação de } \\
\text { se expressar durante o } \\
\text { parto." }\end{array}$ & $\begin{array}{l}\text { "Todo procedimento } \\
\text { /comportamento que } \\
\text { desrespeite a autonomia } \\
\text { da mulher dentro do ciclo } \\
\text { gravídico/puerperal. Seja } \\
\text { em situação de pré-natal, } \\
\text { parto, puerpério ou } \\
\text { abortamento." }\end{array}$ \\
\hline $\begin{array}{l}\text { "Toda ação que é contrária } \\
\text { ao adequado } \\
\text { atendimento/acolhimento } \\
\text { da gestante/puérpera e } \\
\text { seus acompanhantes nos } \\
\text { mais variados aspectos } \\
\text { (biopsicossocial)." }\end{array}$ & $\begin{array}{l}\text { parto que transgrida os } \\
\text { direitos da mulher e a } \\
\text { coloque em posição de um } \\
\text { agente passivo, sem } \\
\text { direito a escolhas [...]" }\end{array}$ & $\begin{array}{l}\text { "Agressão (física ou } \\
\text { verbal) à parturiente, } \\
\text { compreendendo desde } \\
\text { realização de } \\
\text { procedimentos sem } \\
\text { consentimento informado, } \\
\text { proibição de desejos da } \\
\text { mesma [...], a utilização de }\end{array}$ \\
\hline $\begin{array}{l}\text { "Submeter [...] a uma } \\
\text { situação em que ela se } \\
\text { sinta constrangida, } \\
\text { acuada, machucar física } \\
\text { ou emocionalmente, não } \\
\text { esclarecer procedimentos, } \\
\text { não pedir consentimento } \\
\text { [..." }\end{array}$ & $\begin{array}{l}\text { "Violar os direitos da } \\
\text { mulher em qualquer } \\
\text { momento da gestação ou } \\
\text { do parto, por parte de um } \\
\text { profissional de saúde." }\end{array}$ & $\begin{array}{l}\text { recursos proscritos ou sem } \\
\text { qualidade de evidência, } \\
\text { bem como pressão } \\
\text { psicológica e comentários } \\
\text { negativos à mãe em } \\
\text { trabalho de parto." }\end{array}$ \\
\hline
\end{tabular}

Fonte: a autora.

Em relação aos fatores que contribuem para a ocorrência da violência obstétrica, a atuação dos profissionais de assistência à saúde foi citada pela maioria dos participantes. As justificativas perpassam desde a formação deficitária e 
desatualização dos profissionais quanto a aspectos mais subjetivos como "falta de humanização", "falta de ética profissional", "abuso de poder", dentre outros. O modelo vigente de assistência obstétrica e a falta de informação por parte da mulher/gestante sobre os seus direitos também foram destaque, conforme alguns relatos apresentados no Quadro 2, abaixo:

Quadro 2: Fatores que contribuem para a ocorrência de violência obstétrica, na visão dos estudantes

\begin{tabular}{|c|c|}
\hline \multirow{4}{*}{$\begin{array}{l}\text { Formação } \\
\text { profissional }\end{array}$} & $\begin{array}{l}\text { "Falta de uma formação mais humanizada aos que lidam com a } \\
\text { gestante." }\end{array}$ \\
\hline & $\begin{array}{l}\text { "Formação profissional pouco humanizada, falta de cursos de } \\
\text { reciclagem dentro dos serviços, protocolos pouco atualizados e/ou } \\
\text { negligenciados pelos profissionais, não poder perder tempo com o } \\
\text { trabalho de parto." }\end{array}$ \\
\hline & $\begin{array}{l}\text { "Profissionais desatualizados e ignorantes. Falta de conhecimento } \\
\text { da população e principalmente das grávidas." }\end{array}$ \\
\hline & "Profissionais não qualificados." \\
\hline \multirow{4}{*}{$\begin{array}{l}\text { Modelo de } \\
\text { assistência }\end{array}$} & $\begin{array}{l}\text { "Talvez o tradicionalismo dos cuidados médicos e de saúde no } \\
\text { geral fortemente enraizado no Brasil." }\end{array}$ \\
\hline & $\begin{array}{l}\text { "Assistência medico-centrada, cultura da doença, cultura de que } \\
\text { quanto mais tecnologias são usadas, ainda que } \\
\text { desnecessariamente, mais seguro está a assistência." }\end{array}$ \\
\hline & $\begin{array}{l}\text { "Hegemonia médica no atendimento em obstetrícia, além do baixo } \\
\text { conhecimento da população atendida e empoderamento feminino." }\end{array}$ \\
\hline & $\begin{array}{l}\text { "Tradicionalismo. Hábitos talvez culturais em acreditar numa } \\
\text { condição hierárquica na relação médico-paciente em detrimento do } \\
\text { consentimento do paciente. Fazer o que é mais rápido." }\end{array}$ \\
\hline \multirow{5}{*}{ Gestante } & $\begin{array}{l}\text { "A falta de conhecimento dos seus direitos por parte da gestante e } \\
\text { seu acompanhante" }\end{array}$ \\
\hline & $\begin{array}{l}\text { "Falta de um pré-natal que esclareça e trabalhe sobre o plano de } \\
\text { parto, que contribua para o empoderamento e confiança da mulher } \\
\text { em si mesma e na equipe que irá acompanhar ou realizar o parto" }\end{array}$ \\
\hline & "O desconhecimento por parte dos pacientes" \\
\hline & "Falta de denúncia por parte da violentada" \\
\hline & "Desinformação, vulnerabilidade, falta de acompanhamento" \\
\hline
\end{tabular}

Fonte: a autora. 
Diniz et al (67), apontam que "a formação dos profissionais de saúde, em especial dos médicos, tem papel estruturante no desenho atual da assistência e na resistência à mudança". Esses autores relatam ainda a utilização de bibliografia desatualizada para a formação dos novos profissionais, que são ensinados e orientados a realizar procedimentos sem a devida comprovação científica e a utilizar as mulheres como cobaias em seu aprendizado - visando o interesse da prática clínica e não da atenção à saúde.

Em relação às críticas tecidas ao modelo de assistência, Davis-Floyd (4) descreve o sistema médico ocidental como "founded in science, effected by technology, and carried out through large institutions governed by patriarchal ideologies in a profit-driven economic context". Isso se revela através da hierarquia presente nas instituições de saúde centrada na autoridade profissional e protocolos padronizados, dentro dos quais o paciente é que deve se adequar.

A utilização da tecnologia deve estar em harmonia com os processos biológicos naturais e acompanhados por cuidados de saúde humanizados. Para Wagner (70), a primeira estratégia deve ser a educação, pois a questão ética fundamental não é o direito de escolher ou exigir determinada conduta, mas sim o direito de receber e discutir a informação completa antes de qualquer procedimento. Por fim, o autor afirma que a segunda estratégia deve ser a promoção de práticas baseadas em evidências científicas.

Odent (71) defende que o controle médico no processo de atenção ao parto configuraria uma "corrupção do papel da medicina". Para o autor, o papel da medicina em geral - e da obstetrícia em particular - originalmente se limita ao tratamento de situações patológicas ou anormais, o que não incluiria o controle de processos fisiológicos.

A falta de conhecimento e informação por parte da gestante é apontada como uma vulnerabilidade que a mantém refém dos procedimentos, sem que possa se manifestar de maneira informada sobre as condutas. A omissão de informações ou sua transmissão em linguagem pouco acessível, o desrespeito, a desconsideração aos valores culturais das gestantes e parturientes também são formas de violência obstétrica (18).

Ao serem questionados sobre como tomaram conhecimento da discussão sobre a ocorrência de violência obstétrica, mais da metade dos participantes citaram 
o meio acadêmico - por meio de aulas, palestras, estágios, debates, dentre outros -, enquanto uma pequena parcela referiu contato devido à prática profissional ou vivência pessoal.

Um terço dos participantes referiu os meios eletrônicos, relatos de casos e a mídia como fonte de informação sobre o assunto - em consonância com o trabalho de Sena e Tesser (72), que apontam a internet "como ferramenta para promover a conscientização, discussão e quebra da invisibilidade da violência obstétrica". Esse número é representativo no contexto da amostra, enquanto fonte de informação fora da academia e ilustra a afirmação das autoras sobre a eficácia da "utilização das mídias alternativas mediadas pela internet como ferramenta de democratização da produção e acesso à informação sobre [...] a violência obstétrica"(72).

\subsubsection{A violência obstétrica dentro instituição de ensino}

Em relação à existência de discussões sobre a violência obstétrica dentro da instituição de ensino à qual pertencem, aproximadamente $80 \%$ respondeu afirmativamente. Por volta de $15 \%$ relataram não haver e $5 \%$ alegaram desconhecer o fato, não havendo diferença expressiva entre entidades de ensino públicas e privadas neste quesito. As atividades promovidas por Ligas Acadêmicas (73) e discussões informais promovidas pelos próprios alunos receberam referências significativas enquanto responsáveis por debater o assunto nas instituições.

$\mathrm{Na}$ questão sobre se houve abordagem, por parte dos professores, sobre a temática da violência obstétrica, $63,7 \%$ dos participantes respondeu que sim sendo que $51 \%$ deles avaliaram positivamente a abordagem realizada e $12,7 \%$ descreveram como insuficiente/superficial - enquanto $36,3 \%$ dos participantes responderam que não houve abordagem, por parte dos professores, sobre 0 assunto.

Silva e colaboradores (74) apontam que, na dimensão ética do processo de aprendizagem as situações precisam ser discutidas com mais clareza, profundidade no conhecimento e adequação às realidades vivenciadas pelas mulheres. Os 
autores destacaram a necessidade de redirecionar as estratégias de ensinoaprendizagem, de modo a oportunizar ao aluno experiências significativas, liberdade para pensar e questionar e o desenvolvimento de ações interativas, humanas e solidárias, bem como espaço para atuar com autonomia, para que possa desenvolver seu potencial crítico-reflexivo.

Ao serem questionados sobre possíveis semelhanças e diferenças que percebiam entre a teoria aprendida e a prática, vivenciada em campos de estágio ou atuação profissional, a maioria dos participantes referiu ter presenciado bastante diferença entre aquilo aprendido e o que era executado dentro das instituições de saúde. Conforme demonstrado por algumas respostas:

"Hoje muitas mulheres estão informadas sobre os riscos e benefícios dos tipos de parto e muito se discute na Universidade (UnB) sobre o assunto, entretanto, na prática, muitos profissionais não permitem que as gestantes decidam sobre o tipo de parto, omitem informações relevantes para a tomada de decisão sobre o parto e o plano de parto, não permitem que as gestantes escolham os acompanhantes e que eles permaneçam ao lado delas durante o trabalho de parto, entre outros."

"Apesar de muito discutido e facilmente encontrado em artigos, as ações humanizadas ainda são pouco praticadas pelos profissionais. Os direitos da gestante também são pouco exercidos e exigidos pelas mesmas."

"A grande diferença percebida entre as duas está nas vezes a técnica se sobrepõe aos valores e culturas e por isso muitas vezes ferem a integridade feminina."

Foi possível perceber na fala de alguns alunos a frustração por presenciar a violência e não possuírem autonomia para modificar a situação, conforme relatado nos trechos a seguir:

"Na teoria, aprendemos tudo o que é preconizado para um bom atendimento às mulheres e também obtemos conhecimento sobre todos os aspectos da violência e as evidências científicas que contrapõem 0 ato violento. Mas, na prática, é difícil separar o que são, ou não, atos violentos devido a institucionalização das violência dentro dos serviços de saúde. Muitas vezes observei a violencia obstétrica sendo realizada dentro da maternidade do Hub, mas, quando questionei o ato, fui repreendida pelo profissional que disse ser algo "comum" e "rotineiro" dentro do serviço e eu, como aluna, não tenho posição para questionar um médico ou enfermeiro 
especializado! Essas atitudes nos desmotivam pois, não temos uma voz ativa dentro da instituição e não conseguimos impedir tal violência."

"Na teoria é algo que da pra resolver, na prática não a gente como acadêmico não pode falar nada apenas observar o que se torna muito revoltante."

Os achados correspondem ao encontrado na literatura, como relatado por Busanello e colaboradores (75) que identificaram a ocorrência de práticas adequadas e inadequadas durante atendimento a adolescentes grávidas. Os autores destacaram a necessidade de se incentivar a utilização de procedimentos que possuem embasamento científico e que estejam inseridos dentro da proposta de humanização do parto.

Em consonância com a fala dos participantes, Ataide e colaboradores (76) constataram que os profissionais de saúde, em sua maioria, demonstram conhecer as condutas, porém a prática realizada não é condizente com o conhecimento informado - conforme constatado em estudo visando comparar o conhecimento teórico dos profissionais, sobre procedimentos preconizados, e sua aplicação prática na enfermagem obstétrica.

Quando questionados se já haviam vivenciado ou tinham conhecimento de alguma situação de violência obstétrica, $82,4 \%$ dos participantes responderam afirmativamente. Destes, 62\% referem pertencer à enfermagem e $18 \%$ à medicina. Novamente, é possível inferir que esse dado se refere ao fato de que ambas as áreas possuem atuação direta na assistência ao parto e nascimento. 


\subsection{BIOÉTICA E A VIOLÊNCIA OBSTÉTRICA, UMA APROXIMAÇÃO}

Ao serem questionados sobre possuir algum conhecimento em Bioética, aproximadamente $65 \%$ dos participantes responderam afirmativamente e menos de $10 \%$ informou não possuir, conforme ilustrado Tabela 4. Não foi possível estabelecer comparações entre os cursos e instituições de ensino no que se refere ao conhecimento de Bioética, por se tratar de amostra pequena e que não teve como foco esse tipo de abordagem. Desta forma, a organização por cursos na tabela teve finalidade apenas didática.

Tabela 4: Conhecimento auto referido em bioética pelos participantes

\section{POSSUI ALGUM CONHECIMENTO DE BIOÉTICA?}

\begin{tabular}{ccccc}
\hline & & SIM & NÃO & TALVEZ \\
\hline & Enfermagem & 46 & 04 & 11 \\
& Farmácia & 02 & 02 & 03 \\
ÁREA DE & Fisioterapia & 06 & 01 & 01 \\
FORMAÇÃ̃ & Medicina & 10 & 01 & 09 \\
& Nutrição & - & - & 02 \\
& Psicologia & 01 & 02 & - \\
& Terapia Ocupacional & 01 & - & - \\
\hline & $\mathbf{N}$ & 66 & 10 & 26 \\
& $\%$ & $64,7 \%$ & $9,8 \%$ & $25,5 \%$ \\
\hline
\end{tabular}

Fonte: a autora

Paiva e colaboradores (77) conduziram uma revisão sistemática sobre o ensino da Bioética durante o processo de formação dos profissionais de saúde. Seus achados apontaram por uma unanimidade nas publicações no que se refere ao reconhecimento da importância da formação em bioética para o desenvolvimento moral e ético do estudante. Os autores apontam a importância de adequação dos currículos com inserção da bioética no contexto de várias disciplinas, como forma de preparação para enfrentar as situações com que os alunos irão se deparar durante a prática profissional.

Para Silva (78), caberia aos estudiosos da Bioética

a responsabilidade de fomentar no público em geral o conhecimento sobre os princípios básicos de bioética e seus instrumentos de reflexão, para que se possa agir quando das violações de direitos humanos. Do mesmo modo, seria conveniente que todos os cursos de Direito e de Medicina tivessem em suas grades curriculares a disciplina de educação ambiental lato sensu, ou de bioética stricto sensu, com o escopo voltado a conscientizar os 
profissionais dessas áreas sobre a validade, alcance e importância dos seus princípios. (78)

Apenas um quinto dos participantes não acredita que o conhecimento em bioética, por parte dos profissionais, reduziria a ocorrência de violência obstétrica as respostas destacam que a maioria dos profissionais já possui algum conhecimento na área e ainda assim cometem violência contra as mulheres durante o atendimento obstétrico.

Esse fenômeno é descrito por Wagner (70), que explica que "os peixes não podem ver a água que nadam dentro". Segundo ele, os profissionais de saúde envolvidos na assistência não conseguem enxergar o profundo efeito que suas intervenções provocam.

Entretanto, mesmo entre os que responderam afirmativamente, há consenso de que apenas o conhecimento em bioética não basta, é necessário que haja uma efetiva aplicação dos princípios. Alguns participantes destacam também, como estratégia para a redução da violência, a importância de uma fiscalização mais efetiva, bem como denúncias e punições - com base nas infrações éticas previstas nos respectivos códigos deontológicos profissionais.

Essa alternativa sugerida pelos participantes se justifica conforme o previsto no Código de Ética Médica (79):

\section{É vedado ao médico:}

Art. 1ㅇ - Causar dano ao paciente, por ação ou omissão, caracterizável como imperícia, imprudência ou negligência.

Parágrafo único. A responsabilidade médica é sempre pessoal e não pode ser presumida. (79)

Quando questionados se, em sua opinião, há alguma relação entre o desrespeito aos princípios bioéticos e a violência obstétrica, a resposta afirmativa foi quase unanimidade - apenas dois participantes responderam não possuir conhecimento/opinião, embora tenham assinalados alguns princípios correspondentes, na questão de múltipla escolha seguinte.

Foi solicitado aos participantes que assinalassem, dentre os princípios bioéticos constantes na DUBDH e propostos para a discussão, àqueles cuja violação poderia estar relacionada à ocorrência de violência obstétrica. Na sessão seguinte, 
havia uma lista de práticas que poderiam caracterizar violência obstétrica, para que também marcassem as que consideravam como tal. Ambas as questões eram de múltipla escolha e não traziam limites de respostas.

Quadro 3: Princípios Bioéticos e Violações Obstétricas

\begin{tabular}{|c|c|c|c|}
\hline \multirow{6}{*}{$\begin{array}{c}\text { Dignidade } \\
\text { Humana e } \\
\text { Direitos Humanos }\end{array}$} & \multirow{6}{*}{$80 \%$} & $\begin{array}{c}\text { Uso de procedimentos } \\
\text { inadequados ou que não deveriam } \\
\text { ser realizados (ex: manobra de } \\
\text { Kristeller) }\end{array}$ & $93 \%$ \\
\hline & & $\begin{array}{l}\text { Violência sexual (toques } \\
\text { excessivos, comentários de cunho } \\
\text { sexual) }\end{array}$ & $89 \%$ \\
\hline & & $\begin{array}{c}\text { Violência física (puxões de cabelo, } \\
\text { tapas, beliscões) }\end{array}$ & $83 \%$ \\
\hline & & $\begin{array}{l}\text { Violência verbal (xingamentos, } \\
\text { ameaças) }\end{array}$ & $83 \%$ \\
\hline & & Desrespeito à lei do acompanhante & $75 \%$ \\
\hline & & $\begin{array}{l}\text { Desrespeito ao direito de ter } \\
\text { consigo uma Doula }\end{array}$ & $55 \%$ \\
\hline \multirow{3}{*}{ Benefício e Dano } & \multirow{3}{*}{$51 \%$} & $\begin{array}{l}\text { Uso de procedimentos } \\
\text { desnecessários ou de forma } \\
\text { rotineira }\end{array}$ & $91 \%$ \\
\hline & & $\begin{array}{c}\text { Indicação de cesariana sem } \\
\text { indicação clínica }\end{array}$ & $86 \%$ \\
\hline & & $\begin{array}{c}\text { Jejum prolongado sem indicação } \\
\text { clínica }\end{array}$ & $76 \%$ \\
\hline \multirow{2}{*}{$\begin{array}{l}\text { Autonomia e } \\
\text { Responsabilidade } \\
\text { Individual }\end{array}$} & \multirow{2}{*}{$56 \%$} & $\begin{array}{l}\text { Impedir a livre expressão da } \\
\text { mulher }\end{array}$ & $84 \%$ \\
\hline & & $\begin{array}{l}\text { Impedir a livre movimentação da } \\
\text { mulher }\end{array}$ & $74 \%$ \\
\hline Consentimento & $64 \%$ & $\begin{array}{l}\text { Uso de procedimentos sem o } \\
\text { consentimento da mulher }\end{array}$ & $87 \%$ \\
\hline $\begin{array}{l}\text { Vulnerabilidade } \\
\text { Humana e } \\
\text { Integridade } \\
\text { Individual }\end{array}$ & $81 \%$ & $\begin{array}{l}\text { Impedir o contato da mulher com } \\
\text { seus familiares }\end{array}$ & $74 \%$ \\
\hline
\end{tabular}

Fonte: a autora. 
Os princípios bioéticos citados por mais da metade dos participantes foram relacionados às práticas sugeridas como possíveis violências. Os números estão representados no Quadro 3, acima.

\subsubsection{Dignidade Humana e Direitos Humanos}

Assinalado por aproximadamente $80 \%$ dos participantes, o respeito à dignidade humana e os direitos humanos podem ser utilizados como principal referencial bioético para o combate às formas de violência obstétrica. Essa relação já foi proposta por Diniz (80), em sua tese de doutorado, onde defende que condutas desnecessárias e arriscadas configuram violações à integridade corporal da mulher - o que configuraria uma violação aos direitos humanos.

Aguiar e d'Oliveira (25) relatam que, "no contexto da assistência em maternidades, a paciente é duplamente objetificada: seu corpo é tomado como objeto de controle e domínio da medicina e como meio para se chegar a um fim - o bebê", sendo vista como "não-sujeito". Os autores ressaltam a importância da "qualidade ética das interações em uma perspectiva ampla de cuidado", de modo que a mulher seja valorizada enquanto sujeito na relação profissional/paciente. Essa perspectiva de cuidado é corroborada por Oliveira (81), que defende que, na esfera bioética, a noção de dignidade humana está centrada numa exigência de não instrumentalização da pessoa.

Em outro trabalho conduzido por Albuquerque (82), foi investigada a introdução do referencial dos direitos humanos na formação médica. Os resultados apontaram que embora o termo "direitos humanos" não esteja expresso especificamente, a temática pode ser inferida pelo perfil profissional médico que se pretende formar, de acordo com as Diretrizes Curriculares Nacionais para os Cursos de Graduação em Medicina. Conforme reflexão da autora,

reconhece-se que a passagem do preconizado pelas Diretrizes para os currículos de graduação é um processo gradativo, já é um avanço considerável ter a alusão aos direitos humanos expressa nas Diretrizes, o próximo passo é concretizá-las por meio da inserção do referencial dos direitos humanos notadamente nas disciplinas que já fazem parte dos currículos, como Bioética e outras de conteúdo humanístico, ou de modo 
transversal, dialogando com os conteúdos das variadas disciplinas do currículo. (82)

Silva (78) defende ser "necessário que a noção de dignidade humana e os pressupostos dos direitos humanos sejam constantemente reafirmados como princípios inerentes e inalienáveis de todos os indivíduos". A utilização desses referenciais encontra respaldo para além da bioética, tendo em vista se tratar de princípio fundamental previsto na constituição brasileira - "ápice da pirâmide do ordenamento jurídico brasileiro" (78).

Dentro da categorização proposta para a violência obstétrica, o "uso de procedimentos inadequados ou que não deveriam ser realizados" foi selecionado por cerca $93 \%$ dos participantes, seguido por "violência sexual" e "violência física" (89\%, cada), "violência verbal" (83\%), "desrespeito à lei do acompanhante" (75\%) e "desrespeito ao direito de ter consigo uma doula" (55\%). Esses achados são condizentes com as respostas dadas, pelos participantes, sobre o que configura a violência obstétrica - uma vez que a maioria cita agressões verbais e físicas na questão aberta sobre o conceito de violência obstétrica.

\subsubsection{Respeito pela Vulnerabilidade Humana e pela Integridade Individual}

O princípio do respeito pela vulnerabilidade humana e pela integridade individual foi o segundo mais apontado, por cerca de $81 \%$ dos participantes. Importante destacar que, embora os princípios de um modo geral possam ser atribuídos dentro de violações aos direitos humanos e à dignidade (motivo pelo qual recebeu grande destaque), o "respeito pela vulnerabilidade humana e pela integridade individual" traz uma ligação direta com esses princípios.

A vulnerabilidade da mulher no processo de parto está relacionada, principalmente, ao desconhecimento sobre seus direitos, seu corpo e sobre que tipo de assistência deveria ser prestada. Além da vulnerabilidade social ante a esse desconhecimento e da vulnerabilidade de gênero (84), há ainda a vulnerabilidade programática, estabelecida pela rotina adotada no parto e a forma como o serviço de saúde e os profissionais estão organizados. 
Essa dinâmica faz com que a submissão da mulher aos protocolos hospitalares seja visto como algo positivo, estabelecendo uma ideia de hierarquização entre profissional-gestante, estabelecendo o procedimento e o sujeito técnico como autores do processo e retirando da mulher a autonomia de seu próprio parto. (84)

Relatório produzido pelo IBC-UNESCO (45) sobre vulnerabilidade tem um capítulo dedicado a discutir a vulnerabilidade no ambiente de saúde. Dentre os tópicos elencados há o acesso aos cuidados, a prestação de saúde adequada e a desigualdade de poder na área de saúde, onde todos se aplicam enquanto vulnerabilidades a que a mulher estaria exposta durante o cuidado obstétrico.

Embora na compilação didática realizada no quadro o único item associado seja "impedir o contato da mulher com seus familiares", marcado por $74 \%$ dos participantes, diversas outras categorias de violência poderiam ser atribuídas a violações desse princípio - uma vez que, quando há violação da integridade individual, pode-se dizer que houve também uma violação à dignidade da pessoa e vice-versa.

\subsubsection{Consentimento e Autonomia}

O desrespeito ao princípio do consentimento foi referido por $64 \%$ dos participantes, enquanto a autonomia e responsabilidade individual recebeu representação de apenas 56\%. Esse dado é curioso, uma vez que o princípio do consentimento possui implicação direta com a autonomia, sendo muitas vezes tratados como extensão um do outro. Assim como estabelecido por Silva (78), "[...] se manifestar por meio do consentimento informado. Critério bioético baseado no princípio da autonomia[...]. Considerando que todo e qualquer procedimento e conduta no âmbito da assistência à saúde deve estar pautado no consentimento e na autonomia dos pacientes, o percentual de participantes que assinalou esses itens denota uma preocupante desconsideração desses aspectos. 
Conforme já descrito anteriormente, o consentimento é utilizado no contexto da prática clínica e pesquisa com seres humanos e é considerado o instrumento que concretiza o respeito à autonomia do indivíduo. Essa relação entre consentimento e autonomia - além dos direitos humanos - também é descrita por Oliveira (82):

Sendo assim, garantir o direito ao consentimento informado, dimensão fundamental do direito humano à saúde, implica adotar políticas, programas e protocolos que respeitem a autonomia e a dignidade humana do paciente, assim como encampar medidas de apoio e proteção endereçadas ao fortalecimento das redes comunitárias existentes das quais fazem parte. Por fim, repisa-se que o direito ao consentimento informado se perfaz no processo de atenção à saúde e interage permanentemente com o direito à informação, o qual se interliga com o direito à educação, o que exemplifica a imbricação entre o consentimento informado com o respeito, a proteção e realização dos direitos humanos. (82)

Considerando que a autonomia implica em liberdade de escolha, estudo realizado no Rio Grande do Sul (85) problematiza a escolha da via de parto (autonomia ou indução?). As autoras concluíram que a falta de informação e a ausência de um cuidado humanizado, faz com que mulheres optem por cesáreas - 0 que, diante da ausência de uma possibilidade real de escolha, faz com que essa opção não configure ação autônoma.

Os dados da pesquisa "Nascer no Brasil" (86), coordenada pela Fiocruz, apontam a mesma situação: $70 \%$ das brasileiras deseja um parto normal no início da gravidez. Entretanto, segundo dados da pesquisa o índice nacional de cesarianas era de $52 \%$ - chegando a $88 \%$ no setor privado e $46 \%$ no setor público. Para além dos multifatores implicados, esses dados mostram a ausência de autonomia legítima das mulheres no que se refere à escolha do tipo de parto. $(87,88)$

Nas categorias de violência, o "uso de procedimentos sem o consentimento da mulher" foi assinalado por $87 \%$ das pessoas. No contexto de assistência ao parto, essa violação costuma ser frequentemente associada ao procedimento de episiotomia - incisão realizada no períneo para "prevenir laceração". Esse procedimento, considerado cirúrgico e que envolve posterior sutura, possui alta incidência e é comumente realizado sem o consentimento prévio da mulher, que muitas vezes só toma ciência após sua execução (89-91). A episiotomia de rotina pode ser considerada uma forma de mutilação genital, devido aos danos implicados à mulher - como dor e desconforto, além de maior risco de infecção (93). 
Em relação a "impedir a livre expressão da mulher", marcado por $84 \%$ dos participantes, diversos estudos relatam que mulheres são condicionadas a apresentar determinados comportamentos durante o parto - os profissionais referem a preferência por pacientes "colaborativas" e a dificuldade em lidar com as consideradas "escandalosas/queixosas".

\begin{abstract}
O escândalo é definido por elas como: gritar demais e não fazer a força necessária para a expulsão do bebê, berrar, chamar a equipe a todo momento, bater, ficar chamando pelo marido, pela mãe, dizendo que não vai aguentar mais, e ficar mandando tirar o soro. [...] Todas as entrevistadas ressaltaram que, se a mulher fizer escândalo, ela sofrerá maus-tratos dentro das maternidades públicas. Uma informação passada para elas não só por pessoas de seu meio social (mulheres da família, amigas, vizinhas e, até, o marido de uma delas), mas também pelos próprios profissionais de saúde.
\end{abstract} (25)

As práticas caracterizadas como "impedir a livre movimentação da mulher", marcadas por $74 \%$ dos respondentes, incluem "procedimentos que impedem a livre movimentação da parturiente, como monitoração fetal contínua, litotomia (posição de parto deitada, com as pernas sobre a perneira)" (94).

Para Davis-Floyd (4), além da administração rotineira de intravenosos a mulheres em trabalho de parto - que as mantém "umbilicalmente" ligadas à instituição -, a exigência da litotomia (posição deitada, com as pernas apoiadas lateralmente) durante o trabalho de parto é uma das maiores representações de poder do profissional - pois facilita a sua intervenção à mulher. Embora haja evidências sobre a importância da liberdade de posição e movimento durante o trabalho de parto, muitas mulheres ainda são obrigadas a permanecer deitadas (40).

\title{
5.3.4 Benefício e Dano
}

Embora configure a "releitura" de conhecidos princípios bioéticos bastante utilizados no contexto biomédico - a saber, beneficência e não maleficência, segundo a teoria principialista (32) -, a desconsideração ao princípio do benefício e dano foi referido por apenas $51 \%$ dos participantes como relacionado à prática de violência obstétrica. 
Conforme exposto na revisão teórica, a aplicação desse princípio gera controversa uma vez que o dano (a ser minimizado) e o benefício (a ser maximizado) são critérios de difícil definição, sendo sua utilização dada de maneira circunstancial. Cabe ainda ressaltar que essa avaliação, idealmente, deveria ser partilhada entre os profissionais e o paciente.

Entretanto, no que se refere ao atendimento ao parto, o relatório divulgado pela OMS (31) classificando os procedimentos de rotina pode ser utilizado como referencial - como inclusive tem servido de parâmetro em alguns estudos que avaliam práticas assistenciais. Infelizmente esses estudos apontam, de uma maneira geral, que há relevantes registros de "Condutas claramente prejudiciais ou ineficazes e que deveriam ser eliminadas", bem como de "Condutas sem evidência suficiente e que devem ser usadas com precaução" $(87,93,95)$.

O "uso de procedimentos desnecessários ou de forma rotineira" foi apontado por $91 \%$ dos participantes, enquanto prática que consideram violência obstétrica. A "indicação de cesariana sem indicação clínica" foi assinalada por 86\% e "jejum prolongado sem indicação clínica” por 76\%. Todas essas categorias podem ser analisadas com bastante eficácia com a devida aplicação do princípio do benefício e dano, uma vez que se trata de procedimentos que possuem indicações (benéficas) reais, mas não devem ser usados indiscriminadamente devido ao dano associado.

\subsubsection{Demais princípios}

Embora não estejam relacionados no Quadro 2, os princípios de "Não discriminação e não estigmatização" (49\%), "Respeito pela Diversidade Cultural e pelo Pluralismo" (42\%), "Privacidade e Confidencialidade" (38\%) e "Igualdade, Justiça e Equidade" (32\%) também constavam como opção na lista disponibilizada para seleção de múltipla escolha.

Embora os números de participantes que assinalaram esses princípios sejam suficientemente representativos, a menor opção por esses itens pode ser explicada por se tratar de princípios de base mais ideológica e social, que demandam maior reflexão quanto a todo o contexto do atendimento em saúde. Entretanto, há que se 
discutir se as questões técnicas ganham maior destaque na discussão por se tratar de estudantes da área da saúde ou se as demais questões simplesmente não são respeitadas pelos estudantes e profissionais.

A discriminação social na assistência ao parto, conforme estudo conduzido por d'Orsi et al (96), pode implicar em maior violência. As mulheres de cor preta ou parda apresentaram menor chance de privacidade durante a assistência ao parto, bem como menor satisfação com o tempo de espera. Em relação à ocorrência de violência física, verbal ou psicológica, houve maior incidência entre mulheres atendidas no setor público e residente na Região Nordeste do país. Pode-se inferir então a violação aos princípios da não discriminação e não estigmatização, bem como desrespeito à privacidade.

De maneira simplificada, o respeito à diversidade cultural da mulher no momento do parto se refere a permitir que ela manifeste a sua crença e costumes, de maneira livre, se assim o desejar. O respeito ao pluralismo está pautado em uma interação harmoniosa entre pessoas e grupos com identidades culturais distintas.

Considerando a complementaridade na aplicação dos princípios bioéticos, que devem ser compreendidos como sendo inter-relacionados, o texto da DUBDH (8) reitera a necessidade de ser considerada em sua totalidade. Conforme discutido ao longo desta seção, é consistente a utilização dos princípios enquanto norteadores das práticas em saúde no que se refere à assistência ao parto e possível afirmar que as práticas de violência obstétrica possuem relação direta ao desrespeito a esses preceitos bioéticos.

Embora não haja necessidade de elencar princípios mais ou menos relevantes ao contexto, é explícito o destaque dos direitos humanos enquanto elo conector entre os demais princípios. Desta forma, destaca-se a importância da sua utilização enquanto referencial na defesa das mulheres vítimas de violência obstétrica e sugere-se novos estudos nesse sentido, analisando de maneira mais aprofundada a violência obstétrica sob a ótica da Bioética clínica e dos direitos humanos dos pacientes.

No que se refere às limitações deste estudo, conforme já mencionado anteriormente, a amostra pequena e por conveniência não permitiu analisar possíveis variáveis como área de formação, instituição de ensino (pública/privada), 
espiritualidade, dentre outros aspectos, e sua relação com a percepção dos estudantes. Da mesma maneira, entende-se que a amostra possua determinado viés de seleção, uma vez que o questionário eletrônico demanda certa iniciativa do participante e permite com que a adesão ao estudo seja pautada em interesse prévio sobre o assunto. Sugere-se então que haja novas pesquisas utilizando outras metodologias de coleta, que possibilitem identificar a real familiaridade dos estudantes sobre as temáticas.

Outro aspecto limitante se refere ao desconhecimento sobre qual bioética os participante se referem quando afirmam possuir o conhecimento a respeito do tema. O questionamento é relevante uma vez que o ensino de bioética é comumente relacionado ao estudo da deontologia e da ética profissional, dentro dos currículos acadêmicos. Diante disso, destaca-se a proposta de Maluf e Garrafa (97) para a utilização do Core Curriculum da UNESCO como ferramenta pedagógica para o ensino de bioética, por se tratar de material produzido com base na Declaração Universal sobre Bioética e Direitos Humanos, que contém elementos teóricos e apresentação de casos complexos para facilitar a prática docente.

\subsubsection{Relato de caso}

Dentro das respostas fornecidas ao questionário, surgiram relatos de participantes sobre uma situação de violência obstétrica presenciada por alunos, da Universidade de Brasília, durante a sua atuação em campos de estágio. O caso aqui relatado é emblemático sobre como se dá o processo de ensino e aprendizagem e a postura institucional no que se refere a violações de direitos das mulheres.

Ao serem questionados sobre a existência de informações sobre a violência obstétrica no contexto da instituição de ensino, os alunos relataram uma situação vivenciada pelos colegas. Pela fala dos estudantes, percebe-se certo descontentamento com a postura da instituição quanto ao ocorrido, conforme algumas respostas: 
"O assunto foi discutido em minha instituição de ensino devido a uma ocorrência de violência obstétrica num dos hospitais que os alunos frequentavam"

"Há entre os estudantes devido a um caso ocorrido no internato, entretanto, até o momento, não houve qualquer menção à situação de violência obstétrica no país por parte dos docentes do curso. " (grifo da autora)

"Não de maneira formal, apenas entre os alunos. A FM inclusive tentou acobertar o caso de violência obstétrica que foi denunciado por um interno da unb e levou retaliação dos médicos do hospital onde ocorreu. Ao invés de promover uma ampla conversa, a faculdade tentou abafar a situação é um professor chegou a culpar o aluno, chamando a atitude da denúncia de "covarde"." (grifo da autora)

Conforme relato dos participantes dessa pesquisa, durante o estágio na maternidade do Hospital Regional de Samambaia, os alunos puderam presenciar práticas que caracterizaram como "violência física" - tais como "episiotomias sem indicação, kristeller, ocitocina e cesáreas de rotina" - e "violência verbal" - "na hora de fazer você não gritou", "faz força senão seu bebê vai morrer", "não precisa desse escândalo todo", conforme destacado pelos respondentes.

Segundo esses participantes, as práticas descritas eram cometidas por toda a equipe de assistência (médicos, enfermeiros e técnicos) e que os demais profissionais se portavam com naturalidade diante dos fatos e "a instituição fingiu desconhecer" e "colocou panos quentes".

Em relação ao processo de denúncia, conforme relatado pelos participantes, foi realizado de maneira anônima, junto ao ministério público, e gerou retaliações. Conforme detalhado na resposta seguinte:

"Um aluno do meu semestre fez uma denúncia ao ministério público. A reação da equipe médica foi terrível e fomos expulsos do hospital de samambaia, não podendo mais estagiar lá. Nos mandaram e-mails com ameaças e deboches na tentativa de desqualificar e intimidar o estudante anônimo. Os professores da área, já no HUB, fizeram uma reunião em que culpavam os alunos pela falta de ambientes práticos para a disciplina, e disseram que a denúncia foi feita por falta de estudo do tal aluno, que não entendia o que estava acontecendo. O ministério público concluiu que as práticas naquele local eram inadequadas e elaborou um pôster com 
orientações as equipes e as famílias, para ser afixado em local visível do HRSAM."

Esses relatos, fornecidos durante a pesquisa, se referem à denúncia feita por um estudante de medicina da UNB ao Ministério Público Federal sobre atos característicos de violência obstétrica que ocorriam no Hospital Regional de Samambaia (HRSAM). Segundo informações constantes no próprio site do MPF (98), após o processo de denúncia "o coordenador de graduação da Faculdade de Medicina da UnB, em vez de apurar os fatos relatados, julgou e recriminou a atitude do estudante de procurar diretamente o MPF sem antes informar a universidade" e os profissionais do HRSAM divulgaram uma nota de repúdio - onde manifestam a decisão de não mais receber os estudantes para estágio na instituição por não haver mais clima de cooperação (99). Diante da postura de ambas as instituições envolvidas, que não tomaram providências imediatas no sentido de averiguar os fatos:

- Ministério Público conseguiu confirmar as informações contidas na denúncia. Por meio de consulta a páginas da rede social Facebook, o MPF verificou dezenas de relatos de violência obstétrica sofrida por gestantes no HRSam e em outros hospitais da rede pública do Distrito Federal, "coincidindo com o senso comum de que dar à luz em maternidades públicas brasileiras encerra alta probabilidade de submissão a diversas formas de violência física e verbal". (98)

Em relação à postura de negação promovida pelas instituições, podemos citar Sena (100), quando aponta que,

o aparente desconforto que existe ao associar a assistência obstétrica a práticas violentas é compreensível, posto que a instituição médica foi criada e construída como instituição respeitável, confiável, legitimada e fortalecida pela hegemonia e saber-poder científico. (100)

Entretanto, D'Oliveira, Diniz e Schraiber (1), apontam que o abuso contra as mulheres é aprendido durante o treinamento e reforçado nas unidades de saúde como meio de controlar as pacientes. $\mathrm{O}$ abuso ocorre principalmente em situações em que a legitimidade dos serviços de saúde é questionável ou questionada, tal qual ocorreu na situação descrita. 
Neste caso, e em muitas situações de violência ou violação de direitos de pacientes, ocorre uma reação corporativista frente ao questionamento acerca de práticas obsoletas ou equivocadas, do ponto científico ou humanista. A resposta ética apresentada no caso é reativa e conservadora do status quo, não havendo manifestação, pelo menos de acordo com os relatos e documentação investigada, de revisão de posturas ou de condenação de práticas desumanas e violentas por parte do serviço.

A presença desse relato de caso na discussão é fruto das inquietações manifestas pelos estudantes quanto ao ocorrido, uma vez que recebem orientações pautadas na humanização do cuidado e da assistência, mas a teoria não encontra reflexo na prática profissional. Para além disso, fica evidente a questão do corporativismo profissional e da negação da violência, por meio do silenciamento do denunciante. As questões implicadas são diversas e exigem uma análise mais aprofundada, sugere-se que seja feito de maneira mais detalhada em um estudo futuro. 


\section{CONSIDERAÇÕES FINAIS}

O estudo conduzido tinha como propósito conhecer a percepção dos estudantes da área da saúde sobre a violência obstétrica e sua relação com a bioética. Para tanto, o referencial bioético escolhido para ser discutido foram os princípios constantes na Declaração Universal sobre Bioética e Direitos Humanos.

Através da fala dos participantes, identificou-se que o conhecimento da temática da violência obstétrica não necessariamente se deu no contexto formal acadêmico, mediado pelos professores e outras ferramentas institucionais. O debate promovido entre alunos e outras fontes de informação - como a internet e a mídia, por meio de relatos de casos - representaram significativa importância nessa aproximação.

No que se refere ao conhecimento em bioética, embora a maioria dos estudantes tenha manifestado familiaridade com o tema, parcela significante demonstrou não possuir conhecimento ou conhecer parcialmente. Considerando a importância da formação ética para profissionais de saúde, expressa nas Diretrizes Curriculares Nacionais para os cursos de enfermagem e medicina há 15 anos, esse dado representa a existência de uma lacuna importante na formação desses profissionais.

Para além do oferecimento de disciplinas de bioética dentro do currículo acadêmico, normalmente associadas ao estudo do respectivo código deontológico profissional, é imprescindível que a instituição de ensino - por meio de seus colaboradores - apresente uma postura coerente dentro dos preceitos éticos e estimule o desenvolvimento do pensamento crítico de seus alunos, ao invés de coibi-los.

Ainda que a amostra utilizada, pequena e de conveniência, apresente limitações, permitiu uma primeira aproximação à perspectiva dos estudantes mediante os temas propostos - o que configura o diferencial da pesquisa. Os achados encontram reflexo em outras pesquisas com aproximações semelhantes e proporcionam elementos para a discussão da formação ética desses futuros profissionais. 
Embora a discussão sobre violência obstétrica esteja gradualmente entrando na academia, sua associação com a bioética ainda é praticamente desconhecida neste contexto. A aproximação entre esses temas permite ampliação do escopo para discussão das temáticas, bem como a possibilidade de adoção de novos referenciais e instrumentos dentro do processo de ensino-aprendizagem.

Propõe-se, como sugestão de ferramenta, a utilização do Core Curriculum de Bioética, da UNESCO, que permite a problematização de dilemas envolvidos na prática profissional em associação com os princípios bioéticos - constantes na Declaração Universal sobre Bioética e Direitos Humanos. Considerando a relação percebida entre a ocorrência de violência obstétrica e a violação aos princípios bioéticos, o material fornecerá subsídios consistentes para a discussão do tema.

A mudança de paradigma e postura dos profissionais envolvidos na atenção à saúde constitui um desafio para o enfrentamento à violência obstétrica. Embora problemas estruturais (de organização do sistema de atenção à saúde e as más condições de trabalho) estejam presentes, o desrespeito à dignidade do paciente bem como adoção de outras condutas não pautadas na ética - por parte dos profissionais, constituiu elemento de destaque dentre os relatos sobre a violência obstétrica.

Na pretensão de que o cenário encontrado possa servir de incentivo para a realização de novas pesquisas, sugere-se a adoção dos referenciais da Bioética Clínica e Direitos Humanos dos Pacientes - que constituem relevantes linhas de reflexão aos problemas éticos implicados no contexto da atenção à saúde - para pautar novas discussões e reflexões bioéticas no contexto da assistência obstétrica. Esses novos referenciais podem ser utilizados de maneira mais consistente em enfoques mais específicos, uma vez que a DUBDH possui escopo muito abrangente.

Reitera-se a necessidade de reflexão, por parte dos docentes, profissionais e instituições de ensino, no que se referem aos anseios apresentados pelos estudantes sobre o corporativismo e a defasagem ética presentes em seu processo de formação profissional. 


\section{REFERÊNCIAS}

1. d'Oliveira AFPL, Diniz SG, Schraiber LB. Violence against women in healthcare institutions: an emerging problem. Lancet. 2002; 359(11):1681-5.

2. World Health Organization. The prevention and elimination of disrespect and abuse during facility-based childbirth. [Internet] WHO; 2014. [acesso 20 out 2014]. Disponível: www.who.int/

3. Rattner D. Humanizing childbirth care: brief theoretical framework. Interface Comunicação, Saúde, Educação. 2009; 13(1):595-602.

4. Davis-Floyd R. The technocratic, humanistic, and holistic models of birth. International Journal of Gynecology \& Obstetrics. 2001; 75(1):5-23.

5. Melo COM, Moreira SNT, Tertulin FF, Azevedo GD. Considerações sobre violência institucional no âmbito da saúde sexual e reprodutiva. Femina. 2008;36(2):p.73-77.

6. Wolff LR, Waldow VR. Consented violence: women in labor and delivery. Saúde e Sociedade. 2008; 17(3):138-151.

7. Garrafa V. Introdução à Bioética. Rev Hosp Universitário UFMA 2005; 6:9-13.

8. Organização das Nações Unidas para a Educação, a Ciência e a Cultura. Declaração Universal sobre Bioética e Direitos Humanos. [Internet]. Paris: Unesco; 2005 [acesso 2014]. Disponível: http://bit.ly/2bOma27

9. Rezende J, Obstetrícia. 5a ed. Rio de Janeiro: Guanabara Koogan, 2001.

10. Fontana Rosane Teresinha. As infecções hospitalares e a evolução histórica das infecções. Rev. bras. enferm. 2006; 59(5): 703-706.

11. Seibert SL, Barbosa JLS, Santos JM, Vargens OMC. Medicalização x Humanização: o cuidado ao parto na história. Rev Enferm UERJ. 2005; 13: 245- 51.

12.Borges LS. Desigualdade e o trabalho de partejar no Brasil: questões para a educação profissional na área materno-infantil. [dissertação] Rio de Janeiro: Escola Politécnica de Saúde Joaquim Venâncio, 2013. 
13. Paciornik, M. Parto de cócoras: aprenda a nascer com os índios. 3aa ed. São Paulo: Brasiliense, 1979.

14. Mott, ML. Assistência ao parto: do domicílio ao hospital (1830-1960). Proj. História. São Paulo, dez 2002.

15. Tornquist CS. Parto e poder: o movimento pela humanização do parto no Brasil. [tese] Florianópolis: Universidade Federal de Santa Catarina; 2004.

16. Mamede FV, Mamede MV, Dotto LMG. Reflexões sobre deambulação e posição materna no trabalho de parto e parto. Escola Anna Nery. 2007; 11(2), 331-336.

17.Diniz CSG. Humanização da assistência ao parto no Brasil: os muitos sentidos de um movimento. Ciência \& Saúde Coletiva. 2005; 10(3), 627-637.

18.PARTO DO PRINCÍPIO. Dossiê da Violência Obstétrica "Parirás com dor". 2012. [acesso 12 jul 2016] Disponível em: http://www.senado.gov.br/comissoes/documentos/SSCEPI/DOC\%20VCM\%20 367.pdf.

19. Ley Orgánica sobre el Derecho de las Mujeres a una Vida Libre de Violencia [Internet]. Gaceta Oficial 38.647. 2007. [acesso 5 nov 15]. Disponível em: http://venezuela.unfpa.org/doumentos/Ley_mujer.pdf.

20.Bowser D, Hill K. Exploring evidence for disrespect and abuse in facility-based childbirth: report of a landscape analysis. Bethesda, Maryland: USAIDTRAction Project; 2010.)

21.Leal MC, Ayres BVS, Esteves-Pereira AP, Sánchez AR, Larouzé B Nascer na prisão: gestação e parto atrás das grades no Brasil. Ciência \& Saúde Coletiva. 2016; 21(7), 2061-2070.

22. Andrade PON, Silva JQP, Diniz CMM, Caminha MFC. Fatores associados à violência obstétrica na assistência ao parto vaginal em uma maternidade de alta complexidade em Recife, Pernambuco. Rev. Bras. Saúde Matern. Infant., $2016 ; 16(1): 29-37$.

23. Santos RCS, Souza NF. Violência institucional obstétrica no Brasil: revisão sistemática. Estação Científica (UNIFAP). 2015; 5(1):57-68.

24. Rodrigues DP, Alves VH, Penna LHG, Pereira AV, Branco MBLR, Silva LA. A peregrinação no período reprodutivo: uma violência no campo obstétrico. Esc Anna Nery 2015;19(4):614-620. 
25. Aguiar JM, d'Oliveira AFPL. Violência institucional em maternidades públicas sob a ótica de usuárias. Interface - Comunic., saúde, educ. 2011; 15(36): 7991.

26. Diniz SG, Salgado HO, Andrezzo, HFA, Carvalho PGC, Carvalho, PCA, Aguiar $\mathrm{CA}$, et al. Violência obstétrica como questão para a saúde pública no Brasil: origens, definições, tipologia, impactos sobre a saúde materna, e propostas para sua prevenção. Rev Bras Crescimento Desenvolv Hum. 2015; 25(3):377-84

27. Seibert SL, Barbosa JLS, Santos JM, Vargens OMC. Medicalização X humanização: o cuidado ao parto na história. Revista de Enfermagem UERJ. 2005; 13:245-51.

28. Rattner D, Santos ML, Lessa H, Diniz SG. ReHuNa - A Rede pela Humanização do Parto e Nascimento. Rev Tempus Actas Saúde Col. 2010; 4(4): 215-228.

29. Busanello J, Kerber NPC, Mendoza-Sassi RA, Mano PS, Susin LRO, Gonçalves BG. Atenção humanizada ao parto de adolescentes: análise das práticas desenvolvidas em um centro obstétrico. Revista Brasileira de Enfermagem. 2011; 64(5), 824-832.

30. Respectful Maternity Care Advisory Council, White Ribbon Alliance for Safe Motherhood. (2011). Respectful maternity care: the universal rights of childbearing women. Washington, DC: WRA. Retrieved [August 8th, 2013] p.1-6.

31. World Health Organization. Care in Normal Birth: A Practical Guide. Maternal and Newborn Health/ Safe Motherhood Unit. Geneva: WHO; 1996. [ acesso 5 fev 2016]

32. Brasil. Ministério da Saúde. Portaria no 1.459, de 24 de junho de 2011. [Internet] [acesso 10 fev 2017] Disponível em: http://bvsms.saude.gov.br/bvs/saudelegis/gm/2011/prt1459_24_06_2011.html

33. Oliveira AAS. Interface entre bioética e direitos humanos: perspectiva teórica, institucional e normativa. 2010. Tese [Doutorado em Ciências da Saúde] Universidade de Brasília, Brasília, 2010. 
34.Andorno R. Global bioethics at Unesco: in defence of the Universal Declaration on Bioethics and Human Rights. J Med Ethics. 2007;33(3):150154.

35. Godoi A, Garrafa V. Leitura bioética do princípio de não discriminação e não estigmatização. Saúde e Sociedade. 2014;23(1):157-166.

36. Beauchamp TL, Childress JF. Principles of biomedical ethics. $7^{\text {a }}$ ed. Nova York: Oxford University Press; 2013.

37.Paranhos FRL, Garrafa V, Melo RL. Estudo crítico do princípio de benefício e dano. Rev. bioét. (Impr.). 2015; 23 (1): 12-9

38. Almeida JLT. Respeito à autonomia do paciente e consentimento livre e esclarecido: uma abordagem principialista da relação médico-paciente. [tese]. [Internet]. Rio de Janeiro: Fundação Oswaldo Cruz; 1999 [acesso 2016]. Disponível: http://bit.ly/2bYVj5A

39. Albuquerque R, Garrafa V. Autonomia e indivíduos sem a capacidade para consentir: o caso dos menores de idade. Rev. bioét. (Impr.). 2016; 23 (1): 129

40.Garrafa V, Martorell LB, Nascimento WF. Críticas ao principialismo em bioética: perspectivas desde o norte e desde o sul. Saúde Soc. São Paulo, v.25, n.2, p.442-451, 2016

41. Selleti JC, Garrafa V. As raízes cristãs da autonomia. Petrópolis: Vozes, 2005.

42. Hostiuc S. Consentimento informado e competência em pediatria: opiniões de uma amostra de médicos romenos em treinamento. J Pediatr. 2012;88(6):51823.

43. Oliveira AAS. Bioética Clínica e Direitos Humanos: a interface entre o direito humano à saúde e o consentimento informado. Centro Universitário São Camilo - 2013;7(4):388-397

44.Cunha T, Garrafa V. Vulnerabilty: A Key Principle for Global Ethics? Cambridge University. 2016; 25(2):197-208.

45.UNESCO. Report of the International Bioethics Committee of UNESCO (IBS). The principle of respect for human vulnerability and personal integrity. 2013.

46. Schramm FR. A Saúde é um direito ou um dever? Autocrítica da saúde pública. Rev. Bras. Bioética. 2006; 2(2): 187-200. 
47.Aguiar JM, d'Oliveira AFPL, Schraiber LB. Institutional violence, medical authority, and power relations in maternity hospitals from the perspective of health workers. Cad. Saúde Pública. 2013; 29(11):2287-2296.

48. Francisconi CF, Goldim JR. Aspectos bioéticos da confidencialidade e privacidade. Iniciação à bioética Brasília: Conselho Federal de Medicina. 1998:264-84.

49. Seoane AF, Fortes PAC. A percepção do usuário do Programa Saúde da Família sobre a privacidade e a confidencialidade de suas informações. Saude soc. [Internet]. 2009 [acesso 2016];18(1):42-49. Disponível em: http://www.scielo.br/scielo.php?script=sci_arttext\&pid=S010412902009000100005 \&lng=en.

50. Cunha L, Patrício ZM. Confidencialidade e privacidade em planos de saúde. Rev. bioét. 2008;16(1):141-54.

51.Silva RC, Soares MC, Jardim VMR, Kerber NPC, Meincke SMK. O discurso e a prática do parto humanizado de adolescentes. Texto Contexto Enferm. 2013; 22(3): 629-36.

52. Azevedo MLN. Igualdade e equidade: qual é a medida da justiça social? Avaliação: Revista da Avaliação da Educação Superior (Campinas), 2013; 18(1):129-150.

53.Garrafa V, Oselka G, Diniz D. Saúde Pública, Bioética e Equidade. Bioética. 1997; 5(1): 27-33.

54. Corgozinho MM, Oliveira AAS. Equidade em saúde como marco ético da bioética. Saúde Soc. São Paulo, v.25, n.2, p.431-441, 2016.

55. Rawls J. Uma teoria da justiça. 2 ed, Martins Fontes. 2002

56.UNESCO. Report of the International Bioethics Committee of UNESCO (IBS). The principle of Non-discrimination and Non-stigmatization. 2014.

57.Diniz CSG, Batista LE, Kalckmann S, Schlitz AOC, Queiroz MR, Carvalho PCA. Sociodemographic inequalities and maternity care of puerperae in Southeastern Brazil, according to skin color: data from the Birth in Brazil national survey (2011-2012). Saúde Soc. 2016; 25(3):561-572.

58. Lorenzo CFG. Desafios para uma bioética clínica interétnica: reflexões a partir da política nacional de saúde indígena. Rev. bioét. 2011;19(2):329-42. 
59. Albuquerque A. Perspectiva Bioética Intercultural e Direitos Humanos: a busca de instrumentos éticos para a solução de conflitos de base cultural. Tempus, actas de saúde colet. 2015; 9(2): 09-27.

60. Feitosa SF, Nascimento WF. A bioética de intervenção no contexto do pensamento latino-americano contemporâneo. Rev. bioét. (Impr.). 2015; 23 (2): 277-84.

61.Gil, AC. Como elaborar projetos de pesquisa. 4ed. São Paulo: Atlas, 2007.

62. Vinuto J. A amostragem bola de neve na pesquisa qualitativa: um debate em aberto. Temáticas, Campinas. 2014; 22(44): 203-220.

63.Bardin L. Análise de conteúdo. Reto LA, Pinheiro A, tradutores. Lisboa: Edições 70; 2011.

64. Brasil. Ministério da Saúde, Conselho Nacional de Saúde. Resolução nำ466, de 12 de dezembro de 2012. [Internet]. [acesso 2014]. Disponível: http://bvsms.saude.gov.br/bvs/saudelegis/cns/2013/res0466_12_1 2_2012.html

65. Instituto Nacional de Estudos e Pesquisas Educacionais Anísio Teixeira. Censo da educação superior 2013: resumo técnico. INEP. Brasília, 2015.

66. Tesser CD, Knobel R, Andrezzo HFA, Diniz SD. Violência obstétrica e prevenção quaternária: o que é e o que fazer. Rev Bras Med Fam Comunidade. 2015;10(35):1-12.

67.Diniz SG, Salgado HO, Andrezzo HFA, Carvalho PGC, Carvalho PCA, Aguiar CA, Niy DY. Abuse and disrespect in childbirth care as a public health issue in Brazil: origins, definitions, impacts on maternal health, and proposals for its prevention. Journal of Human Growth and Development. 25(3): 377-384.

68. Pereira JS, Silva JCO, Borges NA, Ribeiro MMG, Auarek LJ, Souza JHK. Violência Obstétrica: ofensa à dignidade humana. Braz. J. Surg. Clin. Res. 2016; (15)1:103-108.

69. Muniz BMV, Barbosa RM. Problematizando o atendimento ao parto: cuidado ou violência? Memorias Convención Internacional de Salud Pública. [periódico online]. 2012. [acesso 8 dez 2016]. Disponível em: http://www.defensoria.sp.gov.br/dpesp/Repositorio/41/Documentos/artigo \%20parto.pdf 
70.Wagner M. Fish can't see water: the need to humanize birth. International journal of gynaecology and obstetrics. 2001; 75 Suppl 1:S25-37.

71. Odent M. O camponês e a parteira: uma alternativa à industrialização da agricultura e do parto. São Paulo: Ground, 2003.

72. Sena LM, Tesser CD. Violência obstétrica no Brasil e o ciberativismo de mulheres mães: relato de duas experiências. Interface (Botucatu) 2017; 21(60): 209-220.

73.Lima PVSF, Soares ML, Fóes GDR, Machado JR, Santos SM, Alves ED. Liga de humanização do parto e nascimento da Universidade de Brasília: relato de experiência. Revista Eletrônica Gestão \& Saúde ISSN: 1982-4785

74. Silva RM, Gurgel AH, Moura ERF. Ética no processo ensino-aprendizagem em Enfermagem Obstétrica. Rev Esc Enferm USP. 2004; 38(1): 28-36.

75. Busanello J, Kerberll NPC, Sassi Ram, Mano OS, Susin LRO, Gonçalves BG. Atenção humanizada ao parto de adolescentes: análise das práticas desenvolvidas em um Centro Obstétrico. Rev. Bras. Enferm. 64(5): 824-832.

76. Ataide MM, Santos AAP, Silva JMO, Sanches METL. Exame obstétrico realizado pela enfermeira: da teoria à prática. Enferm. Foco. 2016; 7(2):67-71.

77.Paiva LM, Guilhem D, Sousa ALL. O Ensino da Bioética na Graduação do Profissional de Saúde. Medicina (Ribeirão Preto) 2014;47(4):357-69.

78. Silva, HB. O princípio da dignidade humana na Constituição brasileira. Revista Bioética 2010; 18(3): 573-87.

79. Resolução CFM № 2.126/2015. Código de Ética Médica. Publicado no D.O.U., 01 de outubro de 2015, Seção I, p. 131. Disponível: http://www.portalmedico.org.br/resolucoes/CFM/2015/2126_2015.pdf

80. Diniz CSG. Entre a técnica e os direitos humanos: possibilidades e limites da humanização da assistência ao parto. São Paulo. Tese [Doutorado em Medicina Preventiva] - Faculdade de Medicina da USP; 2001.

81. Oliveira AAS. Interface entre bioética e direitos humanos: o conceito ontológico de dignidade humana e seus desdobramentos. Rev. bioét. 2007; 15(2): 170-85.

82. Albuquerque A. Os direitos humanos na formação do profissional de medicina. Rev Med. 2015; 94(3): 169-78. 
83. Garrafa V, Lorenzo C. Helsinque 2008: redução de proteção e maximização de interesses privados. Rev. Assoc. Med. Bras. 2009;55(5):497-520.

84.Griboski RA, Guilhem D. Women and healt care professionals: the role of cultural imagination in the humanization of delivery and childbirth. Texto Contexto Enferm. 2006; 15(1):107-114.

85. Leal MC, Pereira APE, Domingues RMSM, Filha MMT, Dias MAB, NakamuraPereira $\mathrm{M}$ et al. Obstetric interventions during labor and childbirth in Brazilian low-risk women. Cad. Saúde Pública. 2014;30(S):17-47.

86. Leal MC, Silva AA, Dias MA, da Gama SG, Rattner D, Moreira ME, et al. Birth in Brazil: national survey into labour and birth. Reprod Health 2012; 9(5):439445.

87. Domingues RMSM, Dias MAB, Nakamura-Pereira M, Torres JA, d'Orsi E, Pereira APE, et al. Processo de decisão pelo tipo de parto no Brasil: da preferência inicial das mulheres à via de parto final. Cad Saúde Pública. 2014; 30(S):101-16.

88. Leão MRC, Riesco MLG, Schneck CA, Angelo M. Reflexões sobre o excesso de cesarianas no Brasil e a autonomia das mulheres. Ciência \& Saúde Coletiva. 2013;18(8), 2395-2400.

89. Dengo VAR, Silva RS, Souza SRRK, Aldrighi JD, Wall ML, Cancela FZV. A episiotomia na percepção de puérperas. Cogitare Enfermagem, 2016; 21(3):18.

90.Previatti JF, Souza KVS. Episiotomia: em foco a visão das mulheres. Rev. Bras. Enferm. 2007;60(2):197-201.

91.Pitangui ACR, Carvalho NHMG, Siqueira CV, Castro JFL, Araújo RC. Occurrence and factors associated to the practice of episiotomy. Rev enferm UFPE online [Internet] 2014; 8(2): 257-63. [acessado em 2016] Disponível em:

http://www.revista.ufpe.br/revistaenfermagem/index.php/revista/article/view/58 20/pdf_4520

92. Diniz CSG, Chacham AS. The cut above and the cut below: the abuse of caesareans and episiotomy in São Paulo, Brazil. Reproductive Health Matters. 2004;12(23): 100-110. 
93. Amorim MC. Experiências de parto e violação aos direitos humanos: um estudo sobre relatos de violência na assistência obstétrica. Goiânia. Dissertação [Mestrado em Direitos Humanos] - Universidade Federal do Goiás. 2015.

94.Amorim MMR, Porto AMF, Souza ASR. Assistance to the second and third periods of labor based on evidence. Femina. 2010;38(11):583-91.

95.Sousa AMM, Souza KV, Rezende EM, Martins EF, Campos D, Lansky S. Práticas na assistência ao parto em maternidades com inserção de enfermeiras obstétricas, em Belo Horizonte, Minas Gerais. Escola Anna Nery. 2016;20(2):324-331.

96. d'Orsi E, Brüggemann OM, Diniz CSG, Aguiar JM, Gusman CR, Torres JA, Antonia Angulo-Tuesta A, Rattner D, Domingues RMSM. Desigualdades sociais e satisfação das mulheres com o atendimento ao parto no Brasil: estudo nacional de base hospitalar. Cad. Saúde Pública. 2014; 30(1):154-168.

97. Maluf F, Garrafa V. O Core Curriculum da Unesco como Base para Formação em Bioética. Rev. bras. educ. méd. 2015; 39(3): 456-462.

98.ASCOM PRDF. Recomendação do MPF. [acesso 15 set 2016] Disponível em: http://www.mpf.mp.br/df/sala-de-imprensa/noticias-df/mpf-faz-recomendacaopara-impedir-praticas-de-violencia-obstetrica-em-hospitais-do-distrito-federal

99. Correio Braziliense. Aunos denunciam violência obstétrica. [acesso 15 set 2016]

Disponível

em:

http://www.correiobraziliense.com.br/app/noticia/cidades/2016/05/24/interna_c idadesdf,533353/alunos-denunciam-violencia-obstetrica-e-sao-proibidos-deestagiar-no-h.shtml

100. Sena LM. Ameaçada e sem voz, como num campo de concentração. Tese [Doutorado em Saúde Coletiva] Universidade Federal de Santa Catarina. Florianópolis, 2016. 


\section{APÊNDICE A - QUESTIONÁRIO ELETRÔNICO APLICADO}

\section{Violência Obstétrica - Estudantes}

Esse questionário faz parte de uma pesquisa de Mestrado (em Bioética), sob a responsabilidade de Raylla Albuquerque, que tem como um de seus objetivos promover o debate acerca da violência obstétrica com estudantes da área de saúde.

A presente pesquisa foi aprovada pelo Comitê de Ética em Pesquisa da Universidade de Brasília. Para informações: cepfs@unb.br.

Ao responder as questões, você está de acordo com a utilização das informações para a pesquisa, garantida a privacidade e o sigilo da sua identidade.

Se houver qualquer dúvida, é possível entrar em contato através do e-mail ravllaalbuquerques@gmail.com.

${ }^{*}$ Required

1. Idade *

Mark only one oval.

Menor de 20 anos

20 a 25 anos

26 a 30 anos

31 a 35 anos

36 a 40 anos

41 a 45 anos

46 ou mais

2. Sexo*

Mark only one oval.

Feminino

Masculino

Other:

3. Cidade/Estado de origem *
4. Área de formação *
Mark only one oval.
Enfermagem
Fisioterapia
Medicina
Psicologia
Other: 
5. Cursando *

Mark only one oval.

Graduação

Residência

Especialização

Mestrado

Doutorado

6. Instituição de Ensino *

7. Religião *

8. Possui filhos? *

Mark only one oval.

Sim

Não

\section{Violência Obstétrica}

9. O que você entende por violência obstétrica? *

10. Como você tomou conhecimento desse assunto? *

11. Em sua opinião, quais os principais fatores que contribuem para a ocorrência de violência obstétrica? * 
Violência Obstétrica - Estudantes

12. Há discussão sobre o tema em sua instituição de ensino? De que maneira? *

13. Algum professor já abordou o tema? Como você avalia essa abordagem? *

14. Quais as semelhanças e diferenças que você vê entre aquilo ensinado na teoria e a vivência prática relacionada à saúde da mulher/obstetrícia? *

15. Você já vivenciou ou conhece algum caso de violência obstétrica? * Mark only one oval.

Sim Skip to question 16.

Não Skip to question 21.

\section{Detalhes sobre a violência obstétrica}

16. Qual o tipo de violência sofrida? (por você ou conhecido) *

17. Quem cometeu a violência? * 
Violência Obstétrica - Estudantes

18. Qual a postura dos demais profissionais e/ou da instituição perante o ocorrido? *

19. Houve denúncia dessa violência? *

Mark only one oval.

$\operatorname{Sim}$

Não

Other:

20. Em caso positivo, como foi o processo de denúncia?

\section{Bioética}

21. Você possui algum conhecimento de Bioética? * Mark only one oval.

Sim

Não

Talvez

22. Na sua opinião, há alguma relação entre o desrespeito aos princípios Bioéticos e a Violência Obstétrica? 
Violência Obstétrica - Estudantes

23. Quais princípios você destacaria? *

Check all that apply.

Autonomia e Responsabilidade Individual

Dignidade Humana e Direitos Humanos

Benefício e Dano

$\square$ Consentimento

$\square$ Respeito pela Vulnerabilidade Humana e pela Integridade Individual

$\square$ Privacidcde e Confidencialidade

$\square$ Igualdade, Justiça e Equidade

$\square$ Não-Discriminação e Não-Estigmatização

$\square$ Respeito pela Diversidade Cultural e pelo Pluralismo

$\square$ Other:

24. Você acha que o conhecimento de bioética por parte dos profissionais reduziria a ocorrência de violência obstétrica? Explique. "

\section{Detalhes sobre a violência}

25. O que você considera violência obstétrica? *

Check all that apply.

Desrespeito à lei do acompanhante

Desrespeito ao direito de ter consigo uma Doula

- Impedir a livre expressão da mulher

$\square$ Impedir a livre movimentação da mulher

$\square$ Impedir o contato da mulher com seus familiares

$\square$ Indicação de cesariana sem indicação clínica

$\square$ Jejum prolongado sem indicação clínica

$\square$ Uso de procedimentos desnecessários ou de forma rotineira

$\square$ Uso de procedimentos inadequados ou que não deveriam ser realizados (ex: manobra de Kristeller) 
Violência Obstétrica - Estudantes

Esse último espaço é para alguma observação/opinião adicional que você gostaria de fazer, alguma experiência pessoal ou de que tenha conhecimento que gostaria de relatar, desabafo, etc.

26. Observações

Powered by

1. Google Forms. 


\section{ANEXO A - PARECER DE APROVAÇÃO PELO COMITÊ DE ÉTICA}

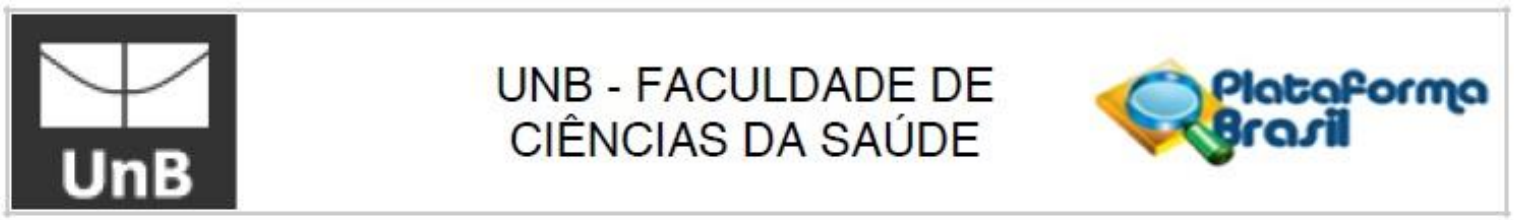

\section{PARECER CONSUBSTANCIADO DO CEP}

\section{DADOS DO PROJETO DE PESQUISA}

Título da Pesquisa: VIOLÊNCIA OBSTÉTRICA À LUZ DOS PRINCÍPIOS DA VULNERABILIDADE E AUTONOMIA

Pesquisador: Raylla Albuquerque Silva

Área Temática:

Versão: 2

CAAE: 59079316.3 .0000 .0030

Instituição Proponente: FACULDADE DE SAÚDE - FS

Patrocinador Principal: Financiamento Próprio

DADOS DO PARECER

Número do Parecer: 1.847 .272

\section{Apresentação do Projeto:}

"Esse projeto tem como objetivo analisar a violência obstétrica no Brasil, do ponto de vista teórico e prático, à luz dos princípios da Vulnerabilidade e da Autonomia. Dentre seus objetivos específicos estão: Identificar a percepção dos estudantes da área de saúde sobre a violência obstétrica; Realizar estudos teóricos sobre a violência obstétrica, os princípios da Vulnerabilidade e da Autonomia; Analisar os achados sobre a violência obstétrica à luz dos princípios da Vulnerabilidade e da Autonomia. Será realizada uma pesquisa exploratória com abordagem mista, sendo o enfoque quantitativo para a determinação de fatores socioeconômicos e demográficos e abordagem qualitativa para a elucidação de valores, conceitos e experiências acerca do tema; o instrumento guia será a entrevista semi-estruturada. Os dados serão transcritos e tabulados pelo programa Excel, apenas para a confecção de gráficos da análise quantitativa, e descritos para interpretação e utilização, por meio de citações anônimas, para a discussão e análise qualitativa. A análise dos princípios da Vulnerabilidade e da Autonomia se dará por meio de referenciais teóricos já publicados e sua aplicação aos achados da pesquisa."

Metodologia Proposta:

"Será realizada uma pesquisa exploratória com abordagem mista, sendo o enfoque

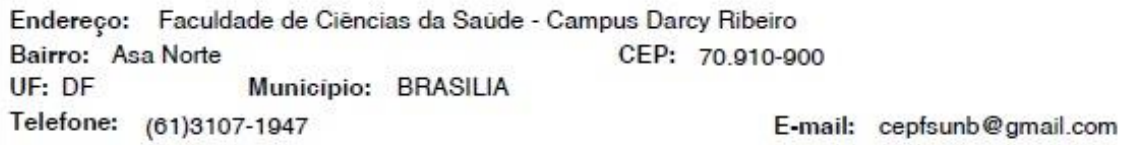




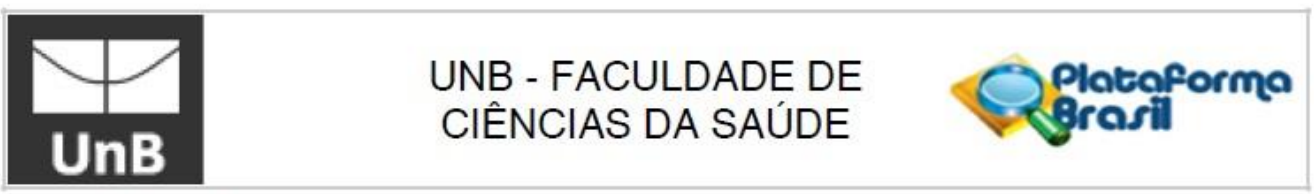

Continuaçāo do Parecer: 1.847.272

O projeto de pesquisa possui todos os itens mínimos para análise ética por este comitê.

Consideraçôes sobre os Termos de apresentação obrigatória:

Foram apresentados os seguintes termos:

- Folha de rosto (folhaDeRosto.pdf em 17/08/2016 e Folharosto.pdf 08/08/2016) - assinada pela Diretora da FS.

- Termo de responsabilidade do pesquisador (TermoResponsabilidadeEditavel.docx em 17/08/2016 e Termoresponsabilidade.pdf em 12/08/2016)

- Carta de encaminhamento ao CEP (CartaEncaminhamentoEditavel.doc e CartaEncaminhamento.pdf em 17/08/2016)

- Projeto Detalhado / Brochura Investigador (Projeto.docx em 12/08/2016)

- Roteiro da entrevista (Roteiroentrevista.docx em 12/08/2016)

- Orçamento (Orcamento.doc em 12/08/2016) prevendo gastos de R\$252,00, com Transporte, gravador, caneta esferográfica e impressão, arcados pela pesquisadora responsável.

- TCLE / Termos de Assentimento / Justificativa de Ausência (TCLE.doc em 11/08/2016) - adeuqado em termos de linguagem e conteúdo.

- Currículos dos pesquisadores.

Após o retorno das pendências, foram apresentados os seguintes termos:

- Projeto Detalhado / Brochura Investigador (Projeto.docx em 12/08/2016)

- Roteiro da entrevista (Roteiroentrevista.docx em 12/08/2016)

- Orçamento (Orcamento.doc em 12/08/2016) prevendo gastos de R\$252,00, com Transporte, gravador, caneta esferográfica e impressão, arcados pela pesquisadora responsável.

- TCLE / Termos de Assentimento / Justificativa de Ausência (TCLE.doc em 11/08/2016) - adeuqado em termos de linguagem e conteúdo.

- Currículos dos pesquisadores.

Após o retorno das pendências, foram apresentados os seguintes termos:

- Projeto Detalhado / Brochura Investigador (Projeto.docx em 08/11/2016)

- Carta de resposta às pendências (CartaRespPendenciasCEPFS.doc e CartaRespostaCEP.pdf em $08 / 11 / 2016)$

- Termo de autorização para uso de imagem e som de voz (TermoAutorizlmagemSomRaylla.doc em $08 / 11 / 2016$ )

Recomendações:

Não se aplica.

Conclusões ou Pendências e Lista de Inadequações:

Solicita-se que as seguintes pendências sejam atendidas:

1. Uma vez que as entrevistas serão gravadas, apresentar Termo de autorização para uso de som de voz, segundo modelo disponivel no site do CEP-FS (www.http://fs.unb.br/cep/index.php/modelos-dedocumentos). PENDÊNCIA ATENDIDA.

2. Descrever como, quando e onde os estudantes serão abordados para recrutamento. PENDÊNCIA

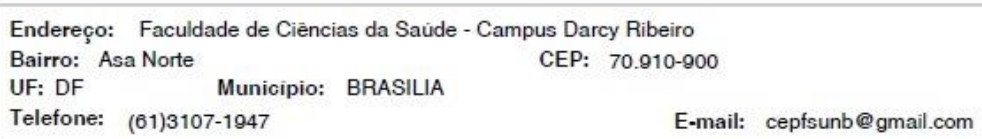




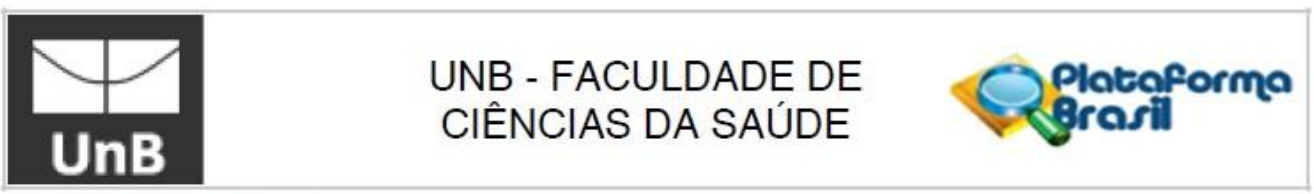

Continuaçāo do Parecer: 1.847.272

O projeto de pesquisa possui todos os itens mínimos para análise ética por este comitê.

Consideraçôes sobre os Termos de apresentação obrigatória:

Foram apresentados os seguintes termos:

- Folha de rosto (folhaDeRosto.pdf em 17/08/2016 e Folharosto.pdf 08/08/2016) - assinada pela Diretora da FS.

- Termo de responsabilidade do pesquisador (TermoResponsabilidadeEditavel.docx em 17/08/2016 e Termoresponsabilidade.pdf em 12/08/2016)

- Carta de encaminhamento ao CEP (CartaEncaminhamentoEditavel.doc e CartaEncaminhamento.pdf em 17/08/2016)

- Projeto Detalhado / Brochura Investigador (Projeto.docx em 12/08/2016)

- Roteiro da entrevista (Roteiroentrevista.docx em 12/08/2016)

- Orçamento (Orcamento.doc em 12/08/2016) prevendo gastos de R\$252,00, com Transporte, gravador, caneta esferográfica e impressão, arcados pela pesquisadora responsável.

- TCLE / Termos de Assentimento / Justificativa de Ausência (TCLE.doc em 11/08/2016) - adeuqado em termos de linguagem e conteúdo.

- Currículos dos pesquisadores.

Após o retorno das pendências, foram apresentados os seguintes termos:

- Projeto Detalhado / Brochura Investigador (Projeto.docx em 12/08/2016)

- Roteiro da entrevista (Roteiroentrevista.docx em 12/08/2016)

- Orçamento (Orcamento.doc em 12/08/2016) prevendo gastos de R\$252,00, com Transporte, gravador, caneta esferográfica e impressão, arcados pela pesquisadora responsável.

- TCLE / Termos de Assentimento / Justificativa de Ausência (TCLE.doc em 11/08/2016) - adeuqado em termos de linguagem e conteúdo.

- Currículos dos pesquisadores.

Após o retorno das pendências, foram apresentados os seguintes termos:

- Projeto Detalhado / Brochura Investigador (Projeto.docx em 08/11/2016)

- Carta de resposta às pendências (CartaRespPendenciasCEPFS.doc e CartaRespostaCEP.pdf em $08 / 11 / 2016)$

- Termo de autorização para uso de imagem e som de voz (TermoAutorizlmagemSomRaylla.doc em $08 / 11 / 2016$ )

Recomendações:

Não se aplica.

Conclusões ou Pendências e Lista de Inadequações:

Solicita-se que as seguintes pendências sejam atendidas:

1. Uma vez que as entrevistas serão gravadas, apresentar Termo de autorização para uso de som de voz, segundo modelo disponivel no site do CEP-FS (www.http://fs.unb.br/cep/index.php/modelos-dedocumentos). PENDÊNCIA ATENDIDA.

2. Descrever como, quando e onde os estudantes serão abordados para recrutamento. PENDÊNCIA

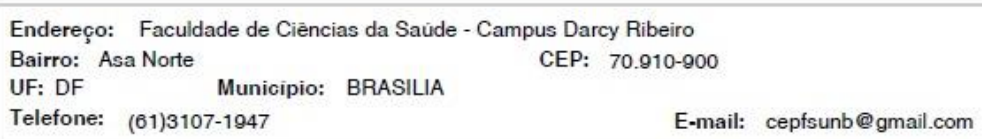




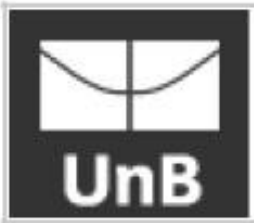

\section{UNB - FACULDADE DE CIÊNCIAS DA SAÚDE}

Continuaçāo do Parecer: 1.847.272

\section{ATENDIDA.}

3. Descrever onde e quando as entrevistas acontecerão, prevendo local que favoreça o sigilo e a confidencialidade das informações prestadas e também o conforto dos participantes. PENDÊNCIA ATENDIDA.

4. Corrigir o cronograma, prevendo início da coleta de dados posterior à aprovação pelo CEP. PENDÊNCIA ATENDIDA.

Conclusão: Todas as pendências foram atendidas. Não há óbices éticos para a realização deste projeto. Protocolo de pesquisa está em conformidade com a Resolução CNS 466/2012 e Complementares.

\section{Considerações Finais a critério do CEP:}

De acordo com a Resolução 466/12 CNS, itens X.1.- 3.b. e XI.2.d, os pesquisadores responsáveis deverão apresentar relatórios parcial semestral e final do projeto de pesquisa, contados a partir da data de aprovação do protocolo de pesquisa.

Este parecer foi elaborado baseado nos documentos abaixo relacionados:

\begin{tabular}{|c|c|c|c|c|}
\hline Tipo Documento & Arquivo & Postagem & Autor & Situação \\
\hline $\begin{array}{l}\text { Informações Básicas } \\
\text { do Projeto }\end{array}$ & $\begin{array}{l}\text { PB_INFORMAÇŐES_BÁSICAS_DO_P } \\
\text { ROJETO_765486.pdf }\end{array}$ & $\begin{array}{c}08 / 11 / 2016 \\
16: 53: 31 \\
\end{array}$ & & Aceito \\
\hline $\begin{array}{l}\text { Projeto Detalhado / } \\
\text { Brochura } \\
\text { Investigador }\end{array}$ & Projeto.docx & $\begin{array}{c}08 / 11 / 2016 \\
16: 50: 13\end{array}$ & $\begin{array}{l}\text { Raylla Albuquerque } \\
\text { Silva }\end{array}$ & Aceito \\
\hline Outros & CartaRespPendenciasCEPFS.doc & $\begin{array}{c}08 / 11 / 2016 \\
16: 16: 43 \\
\end{array}$ & $\begin{array}{l}\text { Raylla Albuquerque } \\
\text { Silva } \\
\end{array}$ & Aceito \\
\hline Outros & CartaRespostaCEP.pdf & $\begin{array}{c}08 / 11 / 2016 \\
16: 16: 06 \\
\end{array}$ & $\begin{array}{l}\text { Raylla Albuquerque } \\
\text { Silva }\end{array}$ & Aceito \\
\hline Outros & TermoAutorizImagemSomRaylla.doc & $\begin{array}{l}08 / 11 / 2016 \\
16: 15: 28\end{array}$ & $\begin{array}{l}\text { Raylla Albuquerque } \\
\text { Silva }\end{array}$ & Aceito \\
\hline Outros & folhaDeRosto.pdf & $\begin{array}{c}17 / 08 / 2016 \\
09: 54: 32 \\
\end{array}$ & $\begin{array}{l}\text { Raylla Albuquerque } \\
\text { Silva }\end{array}$ & Aceito \\
\hline Outros & TermoResponsabilidadeEditavel.docx & $\begin{array}{c}17 / 08 / 2016 \\
09: 47: 04\end{array}$ & $\begin{array}{l}\text { Raylla Albuquerque } \\
\text { Silva }\end{array}$ & Aceito \\
\hline Outros & CartaEncaminhamentoEditavel.doc & $\begin{array}{c}17 / 08 / 2016 \\
09: 45: 14\end{array}$ & \begin{tabular}{|l} 
Raylla Albuquerque \\
Silva \\
\end{tabular} & Aceito \\
\hline Outros & CartaEncaminhamento.pdf & $\begin{array}{c}17 / 08 / 2016 \\
09: 43: 35\end{array}$ & $\begin{array}{l}\text { Raylla Albuquerque } \\
\text { Silva }\end{array}$ & Aceito \\
\hline Outros & Roteiroentrevista.docx & $\begin{array}{c}12 / 08 / 2016 \\
12: 11: 50\end{array}$ & $\begin{array}{l}\text { Raylla Albuquerque } \\
\text { Silva }\end{array}$ & Aceito \\
\hline
\end{tabular}

Endereço: Faculdade de Ciências da Saúde - Campus Darcy Ribeiro

Bairro: Asa Norte

UF: DF Municipio: BRASILIA

CEP: $\quad 70.910-900$

Telefone: (61)3107-1947

E-mail: cepfsunb@gmail.com 


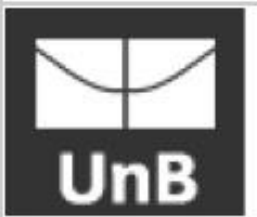

\section{UNB - FACULDADE DE CIÊNCIAS DA SAÚDE}

Continuaçāo do Parecer: 1.847.272

\begin{tabular}{|l|l|c|l|c|}
\hline Outros & Termoresponsabilidade.pdf & $\begin{array}{c}12 / 08 / 2016 \\
11: 28: 47\end{array}$ & $\begin{array}{l}\text { Raylla Albuquerque } \\
\text { Silva }\end{array}$ & Aceito \\
\hline Outros & CurriculoRaylla.pdf & $\begin{array}{c}12 / 08 / 2016 \\
11: 22: 53\end{array}$ & $\begin{array}{l}\text { Raylla Albuquerque } \\
\text { Silva }\end{array}$ & Aceito \\
& & $\begin{array}{c}12 / 08 / 2016 \\
11: 22: 34\end{array}$ & $\begin{array}{l}\text { Raylla Albuquerque } \\
\text { Silva }\end{array}$ & Aceito \\
\hline Outros & CurriculoNatan.pdf & $12 / 08 / 2016$ & $\begin{array}{l}\text { Raylla Albuquerque } \\
\text { Silva }\end{array}$ & Aceito \\
\hline Orçamento & Orcamento.doc & $11: 20: 34$ & $11 / 08 / 2016$ \\
& & $\begin{array}{l}\text { Raylla Albuquerque } \\
\text { Silva }\end{array}$ & Aceito \\
\hline TCLE / Termos de & TCLE.doc & & & \\
Assentimento / & & $08 / 08 / 2016$ & $\begin{array}{l}\text { Raylla Albuquerque } \\
\text { Silva }\end{array}$ & Aceito \\
Justificativa de & & $13: 28: 17$ & \\
\hline Fusência & & Folharosto.pdf & & \\
\hline
\end{tabular}

Situação do Parecer:

Aprovado

Necessita Apreciação da CONEP:

Não

BRASILIA, 25 de Novembro de 2016

Assinado por:

Keila Elizabeth Fontana

(Coordenador)

Endereço: Faculdade de Ciências da Saúde - Campus Darcy Ribeiro

Bairro: Asa Norte

CEP: $70.910-900$

UF: DF

Municipio: BRASILIA

Telefone: (61)3107-1947

E-mail: cepfsunb@gmail.com 


\title{
ANEXO B - DECLARAÇÃO UNIVERSAL SOBRE BIOÉTICA E DIREITOS HUMANOS
}

\author{
DECLARACÃO UNIVERSAL SOBRE BIOÉTICA E DIREITOS HUMANOS
}

\section{TEXTO DA DUBDH}

\section{DECLARAÇÃO UNIVERSAL SOBRE BIOÉTICA E DIREITOS HUMANOS}

Tradução e revisão final sob a responsabilidade da Cátedra UNESCO de Bioética da Universidade de Brasília (UnB) e da Sociedade Brasileira de Bioética (SBB). Tradução: Ana Tapajós e Mauro Machado do Prado.

Revisão: Volnei Garrafa

\section{A Conferência Geral,}

Consciente da capacidade única dos seres humanos de refletir sobre sua própria existência e sobre o seu meio ambiente; de perceber a injustiça; de evitar o perigo; de assumir responsabilidade; de buscar cooperação e de demonstrar o sentido moral que dá expressão a princípios éticos,

Refletindo sobre os rápidos avanços na ciência e na tecnologia, que progressivamente afetam nossa compreensão da vida e a vida em si, resultando em uma forte exigência de uma resposta global para as implicações éticas de tais desenvolvimentos,

Reconhecendo que questões éticas suscitadas pelos rápidos avanços na ciência e suas aplicações tecnológicas devem ser examinadas com o devido respeito à dignidade da pessoa humana e no cumprimento e respeito universais pelos direitos humanos e liberdades fundamentais,

Deliberando ser necessário e oportuno que a comunidade internacional declare princípios universais que proporcionarão uma base para a resposta da humanidade aos sempre crescentes dilemas e controvérsias que a ciência e a tecnologia apresentam à espécie humana e ao meio ambiente,

Recordando a Declaração Universal dos Direitos do Homem, de 10 de Dezembro de 1948, a Declaração Universal sobre o Genoma Humano e os Direitos Humanos, adotada pela Conferência Geral da UNESCO, em 11 de Novembro de 1997 e a Declaração Internacional sobre os Dados Genéticos Humanos, adotada pela Conferência Geral da UNESCO em 16 de Outubro de 2003,

Recordando o Pacto Internacional das Nações Unidas sobre os Direitos Econômicos, Sociais e Culturais e o Pacto Internacional sobre os Direitos Civis e Políticos, de 16 de Dezembro de 1966, a Convenção Internacional das Nações 
Unidas sobre a Eliminação de Todas as Formas de Discriminação Racial, de 21 de Dezembro de 1965, a Convenção das Nações Unidas sobre a Eliminação de Todas as Formas de Discriminação contra as Mulheres, de 18 de Dezembro de 1979, a Convenção das Nações Unidas sobre os Direitos da Criança, de 20 de Novembro de 1989, a Convenção das Nações Unidas sobre a Diversidade Biológica, de 5 de Junho de 1992, os Parâmetros Normativos sobre a Igualdade de Oportunidades para Pessoas com Incapacidades, adotados pela Assembléia Geral das Nações Unidas em 1993, a Convenção de OIT (n. .169$)$ referente a Povos Indígenas e 1 Adotada por aclamação em 19 de outubro de 2005 pela 33a. Sessão da Conferência Geral da UNESCO Tribais em Países Independentes, de 27 de Junho de 1989, o Tratado Internacional sobre Recursos Genéticos Vegetais para a Alimentação e a Agricultura, adotado pela Conferência da FAO em 3 de Novembro de 2001 e que entrou em vigor em 29 de Junho de 2004, a Recomendação da UNESCO sobre a Importância dos Pesquisadores Científicos, de 20 de Novembro de 1974, a Declaração da UNESCO sobre Raça e Preconceito Racial, de 27 de Novembro de 1978, a Declaração da UNESCO sobre as Responsabilidades das Gerações Presentes para com as Gerações Futuras, de 12 de Novembro de 1997, a Declaração Universal da UNESCO sobre a Diversidade Cultural, de 2 de Novembro de 2001, o Acordo sobre os Aspectos dos Direitos de Propriedade Intelectual Relacionados ao Comércio (TRIPS) anexo ao Acordo de Marraqueche, que estabelece a Organização Mundial do Comércio, que entrou em vigor em 1 de Janeiro de 1995, a Declaração de Doha sobre o Acordo de TRIPS e a Saúde Pública, de 14 de Novembro de 2001, e outros instrumentos internacionais relevantes adotados pela Organização das Nações Unidas e pelas agências especializadas do sistema da Organização das Nações Unidas, em particular a Organização para a Alimentação e a Agricultura da Organização das Nações Unidas (FAO) e a Organização Mundial da Saúde (OMS),

Observando, ainda, instrumentos internacionais e regionais no campo da bioética, inc1uindo a Convenção para a Proteção dos Direitos Humanos e da Dignidade do Ser Humano com respeito às Aplicações da Biologia e da Medicina: Convenção sobre Direitos Humanos e Biomedicina do Conselho da Europa, adotada em 1997 e que entrou em vigor em 1999 e seus protocolos adicionais, bem como legislação e regulamentações nacionais no campo da bioética, códigos internacionais e regionais de conduta, diretrizes e outros textos no campo da bioética, tais como a Declaração de Helsinque, da Associação Médica Mundial, sobre Princípios Éticos para a Pesquisa Biomédica Envolvendo Sujeitos Humanos, adotada em 1964 e emendada em 1975, 1989, 1993, 1996, 2000 e 2002, e as Diretrizes Éticas Internacionais para Pesquisas Biomédicas Envolvendo Seres Humanos, do Conselho para Organizações Internacionais de Ciências Médicas, adotadas em 1982 e emendadas em 1993 e 2002, 
Reconhecendo que a presente Declaração deve ser interpretada de modo consistente com a legislação doméstica e o direito internacional, em conformidade com as regras sobre direitos humanos,

Tendo presente a Constituição da UNESCO, adotada em 16 de Novembro de 1945, Considerando o papel da UNESCO na identificação de princípios universais baseados em valores éticos compartilhados para o desenvolvimento científico e tecnológico e a transformação social, de modo a identificar os desafios emergentes em ciência e tecnologia, levando em conta a responsabilidade da geração presente para com as gerações futuras e que as questões da bioética, que necessariamente possuem uma dimensão internacional, devem ser tratadas como um todo, inspirando-se nos princípios já estabelecidos pela Declaração Universal sobre o Genoma Humano e os Direitos Humanos e pela Declaração Internacional sobre os Dados Genéticos Humanos e levando em conta não somente o atual contexto científico, mas também desenvolvimentos futuros,

Consciente de que os seres humanos são parte integrante da biosfera, com um papel importante na proteção um do outro e das demais formas de vida, em particular dos animais,

Reconhecendo, com base na liberdade da ciência e da pesquisa, que os desenvolvimentos científicos e tecnológicos têm sido e podem ser de grande benefício para a humanidade inter alia no aumento da expectativa e na melhoria da qualidade de vida, e enfatizando que tais desenvolvimentos devem sempre buscar promover o bem-estar dos indivíduos, famílias, grupos ou comunidades e da humanidade como um todo no reconhecimento da dignidade da pessoa humana e no respeito universal e observância dos direitos humanos e das liberdades fundamentais,

Reconhecendo que a saúde não depende unicamente dos desenvolvimentos decorrentes das pesquisas científicas e tecnológicas, mas também de fatores psicosociais e culturais,

Reconhecendo, ainda, que decisões sobre questões éticas na medicina, nas ciências da vida e nas tecnologias associadas podem ter impacto sobre indivíduos, famílias, grupos ou comunidades e sobre a humanidade como um todo,

Tendo presente que a diversidade cultural, como fonte de intercâmbio, inovação e criatividade, é necessária aos seres humanos e, nesse sentido, constitui patrimônio comum da humanidade, enfatizando, contudo, que esta não pode ser invocada à custa dos direitos humanos e das liberdades fundamentais,

Tendo igualmente presente que a identidade de um indivíduo inclui dimensões biológicas, psicológicas, sociais, culturais e espirituais,

Reconhecendo que condutas científicas e tecnológicas antiéticas já produziram impacto específico em comunidades indígenas e locais, 
Convencida de que a sensibilidade moral e a reflexão ética devem ser parte integrante do processo de desenvolvimento científico e tecnológico e de que a bioética deve desempenhar um papel predominante nas escolhas que precisam ser feitas sobre as questões que emergem de tal desenvolvimento,

Considerando o desejo de desenvolver novos enfoques relacionados à responsabilidade social de modo a assegurar que o progresso da ciência e da tecnologia contribua para a justiça, a eqüidade e para o interesse da humanidade,

Reconhecendo que conceder atenção à posição das mulheres é uma forma importante de avaliar as realidades sociais e alcançar eqüidade,

Dando ênfase à necessidade de reforçar a cooperação internacional no campo da bioética, levando particularmente em consideração as necessidades específicas dos países em desenvolvimento, das comunidades indígenas e das populações vulneráveis,

Considerando que todos os seres humanos, sem distinção, devem se beneficiar dos mesmos elevados padrões éticos na medicina e nas pesquisas em ciências da vida,

Proclama os princípios a seguir e adota a presente Declaração.

\section{DISPOSIÇÕES GERAIS}

\section{Artigo 1 - Escopo}

a) A Declaração trata das questões éticas relacionadas à medicina, às ciências da vida e às tecnologias associadas quando aplicadas aos seres humanos, levando em conta suas dimensões sociais, legais e ambientais.

b) A presente Declaração é dirigida aos Estados. Quando apropriado e pertinente, ela também oferece orientação para decisões ou práticas de indivíduos, grupos, comunidades, instituições e empresas públicas e privadas.

\section{Artigo 2 - Objetivos}

Os objetivos desta Declaração são:

(i) prover uma estrutura universal de princípios e procedimentos para orientar os Estados na formulação de sua legislação, políticas ou outros instrumentos no campo da bioética;

(ii) orientar as ações de indivíduos, grupos, comunidades, instituições e empresas públicas e privadas;

(iii) promover o respeito pela dignidade humana e proteger os direitos humanos, assegurando 0 respeito pela vida dos seres humanos e pelas liberdades fundamentais, de forma consistente com a legislação internacional de direitos humanos;

(iv) reconhecer a importância da liberdade da pesquisa científica e os benefícios resultantes dos desenvolvimentos científicos e tecnológicos, evidenciando, ao mesmo tempo, a necessidade de que tais pesquisas e desenvolvimentos ocorram 
conforme os princípios éticos dispostos nesta Declaração e respeitem a dignidade humana, os direitos humanos e as liberdades fundamentais;

(v) promover o diálogo multidisciplinar e pluralístico sobre questões bioéticas entre todos os interessados e na sociedade como um todo;

(vi) promover o acesso eqüitativo aos desenvolvimentos médicos, científicos e tecnológicos, assim como a maior difusão possível e o rápido compartilhamento de conhecimento relativo a tais desenvolvimentos e a participação nos benefícios, com particular atenção às necessidades de países em desenvolvimento;

(vii) salvaguardar e promover os interesses das gerações presentes e futuras; e (viii) ressaltar a importância da biodiversidade e sua conservação como uma preocupação comum da humanidade.

\section{PRINCÍPIOS}

Conforme a presente Declaração, nas decisões tomadas ou práticas desenvolvidas por aqueles a quem ela é dirigida, devem ser respeitados os princípios a seguir.

\section{Artigo 3 - Dignidade Humana e Direitos Humanos}

a) A dignidade humana, os direitos humanos e as liberdades fundamentais devem ser respeitados em sua totalidade. b) Os interesses e o bem-estar do indivíduo devem ter prioridade sobre o interesse exclusivo da ciência ou da sociedade.

\section{Artigo 4 - Benefício e Dano}

Os benefícios diretos e indiretos a pacientes, sujeitos de pesquisa e outros indivíduos afetados devem ser maximizados e qualquer dano possível a tais indivíduos deve ser minimizado, quando se trate da aplicação e do avanço do conhecimento científico, das práticas médicas e tecnologias associadas.

\section{Artigo 5 - Autonomia e Responsabilidade Individual}

Deve ser respeitada a autonomia dos indivíduos para tomar decisões, quando possam ser responsáveis por essas decisões e respeitem a autonomia dos demais. Devem ser tomadas medidas especiais para proteger direitos e interesses dosindivíduos não capazes de exercer autonomia.

\section{Artigo 6 - Consentimento}

a) Qualquer intervenção médica preventiva, diagnóstica e terapêutica só deve ser realizada com o consentimento prévio, livre e esclarecido do indivíduo envolvido, baseado em informação adequada. O consentimento deve, quando apropriado, ser manifesto e poder ser retirado pelo indivíduo envolvido a qualquer momento e por qualquer razão, sem acarretar desvantagem ou preconceito.

b) A pesquisa científica só deve ser realizada com o prévio, livre, expresso e esclarecido consentimento do indivíduo envolvido. A informação deve ser adequada, fornecida de uma forma compreensível e incluir os procedimentos para a retirada do consentimento. O consentimento pode ser retirado pelo indivíduo envolvido a qualquer hora e por qualquer razão, sem acarretar qualquer desvantagem ou preconceito. Exceções a este princípio somente devem ocorrer quando em 
conformidade com os padrões éticos e legais adotados pelos Estados, consistentes com as provisões da presente Declaração, particularmente com o Artigo 27 e com os direitos humanos.

c) Em casos específicos de pesquisas desenvolvidas em um grupo de indivíduos ou comunidade, um consentimento adicional dos representantes legais do grupo ou comunidade envolvida pode ser buscado. Em nenhum caso, o consentimento coletivo da comunidade ou o consentimento de um líder da comunidade ou outra autoridade deve substituir o consentimento informado individual.

\section{Artigo 7 - Indivíduos sem a Capacidade para Consentir}

Em conformidade com a legislação, proteção especial deve ser dada a indivíduos sem a capacidade para fornecer consentimento:

a) a autorização para pesquisa e prática médica deve ser obtida no melhor interesse do indivíduo envolvido e de acordo com a legislação nacional. Não obstante, o indivíduo afetado deve ser envolvido, na medida do possível, tanto no processo de decisão sobre consentimento assim como sua retirada;

b) a pesquisa só deve ser realizada para o benefício direto à saúde do indivíduo envolvido, estando sujeita à autorização e às condições de proteção prescritas pela legislação e caso não haja nenhuma alternativa de pesquisa de eficácia comparável que possa incluir sujeitos de pesquisa com capacidade para fornecer consentimento. Pesquisas sem potencial benefício direto à saúde só devem ser realizadas excepcionalmente, com a maior restrição, expondo o indivíduo apenas a risco e desconforto mínimos e quando se espera que a pesquisa contribua com o benefício à saúde de outros indivíduos na mesma categoria, sendo sujeitas às condições prescritas por lei e compatíveis com a proteção dos direitos humanos do indivíduo. A recusa de tais indivíduos em participar de pesquisas deve ser respeitada.

\section{Artigo 8 - Respeito pela Vulnerabilidade Humana e pela Integridade Individual}

A vulnerabilidade humana deve ser levada em consideração na aplicação e no avanço do conhecimento científico, das práticas médicas e de tecnologias associadas. Indivíduos e grupos de vulnerabilidade específica devem ser protegidos e a integridade individual de cada um deve ser respeitada.

\section{Artigo 9 - Privacidade e Confidencialidade}

A privacidade dos indivíduos envolvidos e a confidencialidade de suas informações devem ser respeitadas. Com esforço máximo possível de proteção, tais informações não devem ser usadas ou reveladas para outros propósitos que não aqueles para os quais foram coletadas ou consentidas, em consonância com o direito internacional, em particular com a legislação internacional sobre direitos humanos.

\section{Artigo 10 - Igualdade, Justiça e Eqüidade}

A igualdade fundamental entre todos os seres humanos em termos de dignidade ede direitos deve ser respeitada de modo que todos sejam tratados de forma justa e eqüitativa. 


\section{Artigo 11 - Não-Discriminação e Não-Estigmatização}

Nenhum indivíduo ou grupo deve ser discriminado ou estigmatizado por qualquer razão, o que constitui violação à dignidade humana, aos direitos humanos e liberdades fundamentais.

\section{Artigo 12 - Respeito pela Diversidade Cultural e pelo Pluralismo}

A importância da diversidade cultural e do pluralismo deve receber a devida consideração. Todavia, tais considerações não devem ser invocadas para violar a dignidade humana, os direitos humanos e as liberdades fundamentais nem os princípios dispostos nesta Declaração, ou para limitar seu escopo.

\section{Artigo 13 - Solidariedade e Cooperação}

A solidariedade entre os seres humanos e cooperação internacional para este fim devem ser estimuladas.

\section{Artigo 14 - Responsabilidade Social e Saúde}

a) A promoção da saúde e do desenvolvimento social para a sua população é objetivo central dos governos, partilhado por todos os setores da sociedade.

b) Considerando que usufruir o mais alto padrão de saúde atingível é um dos direitos fundamentais de todo ser humano, sem distinção de raça, religião, convicção política, condição econômica ou social, o progresso da ciência e da tecnologia deve ampliar:

(i) o acesso a cuidados de saúde de qualidade e a medicamentos essenciais, incluindo especialmente aqueles para a saúde de mulheres e crianças, uma vez que a saúde é essencial à vida em si e deve ser considerada como um bem social e humano;

(ii) 0 acesso a nutrição adequada e água de boa qualidade;

(iii) a melhoria das condições de vida e do meio ambiente;

(iv) a eliminação da marginalização e da exclusão de indivíduos por qualquer que seja o motivo; e

(v) a redução da pobreza e do analfabetismo.

\section{Artigo 15 - Compartilhamento de Benefícios}

a) Os benefícios resultantes de qualquer pesquisa científica e suas aplicações devem ser compartilhados com a sociedade como um todo e, no âmbito da comunidade internacional, em especial com países em desenvolvimento. Para dar efeito a esse princípio, os benefícios podem assumir quaisquer das seguintes formas:

(i) ajuda especial e sustentável e reconhecimento aos indivíduos e grupos que tenham participado de uma pesquisa;

(ii) acesso a cuidados de saúde de qualidade;

(iii) oferta de novas modalidades diagnósticas e terapêuticas ou de produtos resultantes da pesquisa;

(iv) apoio a serviços de saúde;

(v) acesso ao conhecimento científico e tecnológico; 
(vi) facilidades para geração de capacidade em pesquisa; e

(vii) outras formas de benefício coerentes com os princípios dispostos na presente Declaração.

b) Os benefícios não devem constituir indução inadequada para estimular a participação em pesquisa.

\section{Artigo 16 - Proteção das Gerações Futuras}

O impacto das ciências da vida sobre gerações futuras, incluindo sobre sua constituição genética, deve ser devidamente considerado.

Artigo 17 - Proteção do Meio Ambiente, da Biosfera e da Biodiversidade Devida atenção deve ser dada à inter-relação de seres humanos com outras formas de vida, à importância do acesso e utilização adequada de recursos biológicos e genéticos, ao respeito pelo conhecimento tradicional e ao papel dos seres humanos na proteção do meio ambiente, da biosfera e da biodiversidade.

\section{APLICAÇÃO DOS PRINCÍPIOS}

\section{Artigo 18 - Tomada de Decisão e o Tratamento de Questões Bioéticas}

a) Devem ser promovidos o profissionalismo, a honestidade, a integridade e a transparência na tomada de decisões, em particular na explicitação de todos os conflitos de interesse e no devido compartilhamento do conhecimento. Todo esforço deve ser feito para a utilização do melhor conhecimento científico e metodologia disponíveis no tratamento e constante revisão das questões bioéticas.

b) Os indivíduos e profissionais envolvidos e a sociedade como um todo devem estar incluídos regularmente num processo comum de diálogo.

c) Deve-se promover oportunidades para o debate público pluralista, buscando-se a manifestação de todas as opiniões relevantes.

\section{Artigo 19 - Comitês de Ética}

Comitês de ética independentes, multidisciplinares e pluralistas devem ser instituídos, mantidos e apoiados em nível adequado com o fim de:

(i) avaliar questões éticas, legais, científicas e sociais relevantes relacionadas a projetos de pesquisa envolvendo seres humanos;

(ii) prestar aconselhamento sobre problemas éticos em situações clínicas;

(iii) avaliar os desenvolvimentos científicos e tecnológicos, formular recomendações e contribuir para a elaboração de diretrizes sobre temas inseridos no âmbito da presente Declaração; e

(iv) promover o debate, a educação, a conscientização do público e o engajamento com a bioética.

\section{Artigo 20 - Avaliação e Gerenciamento de Riscos}

Deve-se promover a avaliação e o gerenciamento adequado de riscos relacionados à medicina, às ciências da vida e às tecnologias associadas. 


\section{Artigo 21 - Práticas Transnacionais}

a) Os Estados, as instituições públicas e privadas, e os profissionais associados a atividades transnacionais devem empreender esforços para assegurar que qualquer atividade no escopo da presente Declaração que seja desenvolvida, financiada ou conduzida de algum modo, no todo ou em parte, em diferentes Estados, seja coerente com os princípios da presente Declaração.

b) Quando a pesquisa for empreendida ou conduzida em um ou mais Estados [Estado(s) hospedeiro(s)] e financiada por fonte de outro Estado, tal pesquisa deve ser objeto de um nível adequado de revisão ética no(s) Estado(s) hospedeiro(s) e no Estado no qual o financiador está localizado. Esta revisão deve ser baseada em padrões éticos e legais consistentes com os princípios estabelecidos na presente Declaração.

c) Pesquisa transnacional em saúde deve responder às necessidades dospaíses hospedeiros e deve ser reconhecida sua importância na contribuição para a redução de problemas de saúde globais urgentes.

d) Na negociação de acordos para pesquisa, devem ser estabelecidos os termos da colaboração e a concordância sobre os benefícios da pesquisa com igual participação de todas as partes na negociação.

e) Os Estados devem tomar medidas adequadas, em níveis nacional e internacional, para combater o bioterrorismo e o tráfico ilícito de órgãos, tecidos, amostras, recursos genéticos e materiais genéticos.

\section{PROMOÇÃO DA DECLARAÇÃO}

\section{Artigo 22 - Papel dos Estados}

a) Os Estados devem tomar todas as medidas adequadas de caráter legislativo, administrativo ou de qualquer outra natureza, de modo a implementar os princípios estabelecidos na presente Declaração e em conformidade com 0 direito internacional e com os direitos humanos. Tais medidas devem ser apoiadas por ações nas esferas da educação, formação e informação ao público.

b) Os Estados devem estimular o estabelecimento de comitês de ética independentes, multidisciplinares e pluralistas, conforme o disposto no Artigo 19.

\section{Artigo 23 - Informação, Formação e Educação em Bioética}

a) De modo a promover os princípios estabelecidos na presente Declaração e alcançar uma melhor compreensão das implicações éticas dos avanços científicos e tecnológicos, em especial para os jovens, os Estados devem envidar esforços para promover a formação e educação em bioética em todos os níveis, bem como estimular programas de disseminação de informação e conhecimento sobre bioética.

b) Os Estados devem estimular a participação de organizações intergovernamentais, internacionais e regionais e de organizações não governamentais internacionais, regionais e nacionais neste esforço. 


\section{Artigo 24 - Cooperação Internacional}

a) Os Estados devem promover a disseminação internacional da informação científica e estimular a livre circulação e o compartilhamento do conhecimento científico e tecnológico.

b) Ao abrigo da cooperação internacional, os Estados devem promover a cooperação cultural e científica e estabelecer acordos bilaterais e multilaterais que possibilitem aos países em desenvolvimento construir capacidade de participação na geração e compartilhamento do conhecimento científico, do know-how relacionado e dos benefícios decorrentes.

c) Os Estados devem respeitar e promover a solidariedade entre Estados, bem como entre indivíduos, famílias, grupos e comunidades, com atenção especial para aqueles tornados vulneráveis por doença ou incapacidade ou por outras condições individuais, sociais ou ambientais e aqueles indivíduos com maior limitação de recursos.

\section{Artigo 25 - Ação de Acompanhamento pela UNESCO}

a) A UNESCO promoverá e disseminará os princípios da presente Declaração. Para tanto, a UNESCO buscará apoio e assistência do Comitê Intergovernamental de Bioética (IGBC) e do Comitê Internacional de Bioética (IBC).

b) A UNESCO reafirmará seu compromisso em tratar de bioética e em promover a colaboração entre o IGBC e o IBC.

\section{CONSIDERAÇÕES FINAIS}

\section{Artigo 26 - Inter-relação e Complementaridade dos Princípios}

A presente Declaração deve ser considerada em sua totalidade e seus princípios devem ser compreendidos como complementares e interrelacionados. Cada princípio deve ser interpretado no contexto dos demais, de forma pertinente e adequada a cada circunstância.

\section{Artigo 27 - Limitações à Aplicação dos Princípios}

Se a aplicação dos princípios da presente Declaração tiver que ser limitada, tal limitação deve ocorrer em conformidade com a legislação, incluindo a legislação referente aos interesses de segurança pública para a investigação, constatação e acusação por crimes, para a proteção da saúde pública ou para a proteção dos direitos e liberdades de terceiros. Quaisquer dessas legislações devem ser consistentes com a legislação internacional sobre direitos humanos.

\section{Artigo 28 - Recusa a Atos Contrários aos Direitos Humanos, às Liberdades}

Fundamentais e Dignidade Humana Nada nesta Declaração pode ser interpretado como podendo ser invocado porqualquer Estado, grupo ou indivíduo, para justificar envolvimento em qualquer atividade ou prática de atos contrários aos direitos humanos, às liberdades fundamentais e à dignidade humana. 